\title{
Glacier recession in Altay mountains after the LIA maximum.
}

\author{
Dmitry Ganyushkin $^{1 *}$, Kirill Chistyakov ${ }^{1}$, Ekaterina Derkach $^{1}$, Dmitry Bantcev $^{1}$, Anton Terekhov ${ }^{2}$, Elena Kunaeva $^{1}$, \\ Valeria Rasputina ${ }^{1}$ \\ 1 Institute of Earth Science, Saint-Petersburg State University, Universitetskaya nab. 7/9, 199034 Saint-Peters- \\ burg, Russia \\ 2 State Hydrological Institute, Vasilyevsky Island, 2nd line, 23, 199004 Saint-Petersburg, Russia \\ * Correspondence: d.ganyushkin@spbu.ru
}

\begin{abstract}
The recent glaciation of the southern part of the Altai is estimated (1256 glaciers with the total area of $559.15 \pm 31.13 \mathrm{~km}^{2}$ ), the area of the glaciers of the whole Altai mountains is evaluated by $1096.55 \mathrm{~km}^{2}$. In the southern part of Altai 2276 glaciers with the total area of $1348.43 \pm 56.16 \mathrm{~km}^{2}$ were reconstructed, the first estimate of the LIA glacial area for the whole Altai mountain system is given $\left(2288.04 \mathrm{~km}^{2}\right)$. Since the LIA the glaciers decrease by $59 \%$ in the southern part of Altai and by $47.9 \%$ for the whole Altai. The ELA in the southern part of Altai increased averagely by $106 \mathrm{~m}$. The higher changes of ELA in relatively humid areas is probably caused by decrease of precipitation. Glaciers of Tavan Bogd glacial center degraded with higher rates after 1968 relative to the interval between 1850-1968. One of the intervals of the fastest shrinkage of the glaciers in 2000-2010 was caused by unfavorable for the glaciers dry and warm interval 1989-2004. However, the fast decrease of the glaciers in 2000-2010 was mainly caused by the shrinkage or disappearance of the smaller glaciers, large valley glaciers started fast retreat after 2010.
\end{abstract}

Keywords: glaciers; Little Ice Age; reconstruction; retreat; Altai

\section{Introduction}

Glaciers are natural indicators of climate, sensitive to its changes [1], this is especially true for the mountain glaciers, which respond more quickly to climatic fluctuations due to their smaller size. Mountain glaciers are the main contributors of glacier melt water that causes rises in sea level [2]. Changes in mountain glaciers also have an impact on runoff [3], which is important for water supply of arid territories [3-6]. Changes in glacial runoff in the mountain areas in some cases cause outbursts of the glacial lakes, sometimes disastrous, activate dangerous exogenous processes [7-9]. Consequently, the study of the dynamics of mountainous glaciers is of great scientific and economic importance [10].

Altai Mountains is a mountain system in Asia, in the south of Siberia and in Central Asia, consisting of high-mountain (the highest point is mount Belukha, $4506 \mathrm{~m}$ a.s.l.) and mid-mountain ranges, separated by deep river valleys and vast intramountain and intermountain basins. It covers an area of over 300,000 km2 and extends approximately 2,000 $\mathrm{km}$ in a northwest-southeast direction. It is located on the territory of four countries: the Russian Federation, China, Mongolia, Kazakhstan (Figure 1). 


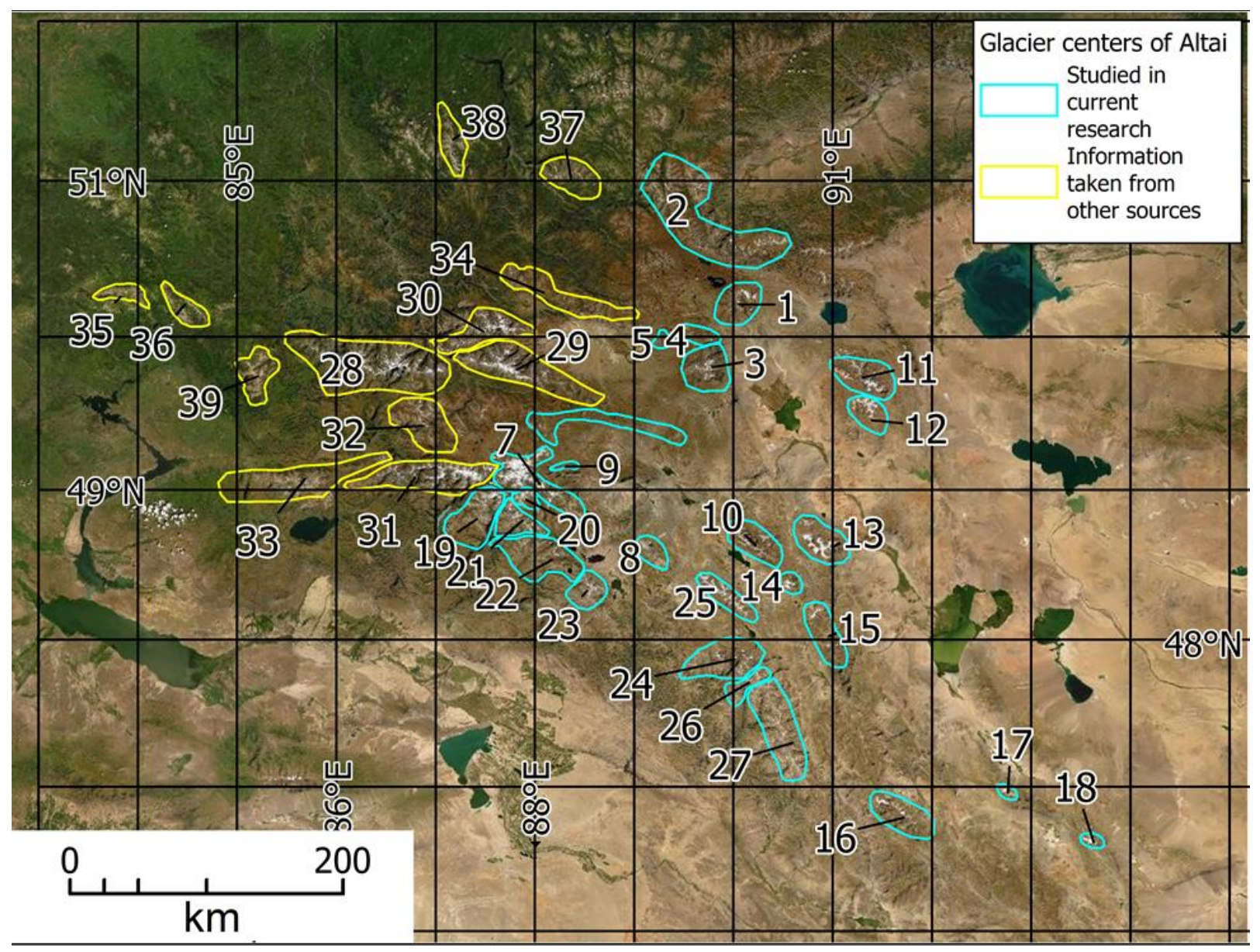

Figure 1. Glacial centers of Altai. 1- Mongun-Taiga, 2-Shapsalsky ridge, 3- Ikh Turgen, 4Mongun-Taiga Minor, 5-Talduayr, 6 -Saylugem, 7- Tavan Bogd, 8-Tsengel Khairkhan, 9- Sogostyn, 10- Hunguyn-Nuru, 11- Turgen, 12- Kharkhiraa, 13-Tsambagarav, 14- Sair, 15- Huh Serh, 16- Munkh Khairkhan, 17- Baatar Khairkhan, 18- Sutai, 19- Sargamyr-Nuru, 20- Alag-Deliyn, 21-North Mongolian Altai, 22- Hoton, 23- Under-Khaikhan, 24- HaritNuru, 25- Bayantyn-Ula, 26- Eule-Tau, 27- Dushin-Ula, 28- Katunsky, 29- South-Chuya, 30- North-Chuya, 31- South Altai, 32- Kara-Alakha, 33- Sarymsakty, 34- Kurai, 35Ivanovskiy, 36- Holzun, 37-Kurkurebazy, 38-Sumulta, 39- Listvyaga

Altai mountainous country has the shape of a triangle in terms of the sharpest peak directed to the southeast. In the central and southeastern parts, many mountain ranges exceed $4000 \mathrm{~m}$ in maximum height, and intermontane depressions are at heights of 1800$2300 \mathrm{~m}$. In the northwestern part, medium-altitude ridges prevail with maximum heights of less than $3000 \mathrm{~m}$. The climate also changes from northwest to southeast: in the northern and northwestern parts of Altai, on the territory of Russia, the amount of precipitation reaches 1000-2500 mm per year. To the southeast, aridity is increasing: in the territory of the Mongolian Altai, the amount of precipitation in the highlands decreases to 200-400 $\mathrm{mm}$, and in the basins does not exceed $200 \mathrm{~mm}$. About $80-85 \%$ of the annual precipitation falls in the warm half of the year, most of them come from the cyclones from the west. Winter precipitation is low owing to the dominance of the Asian anticyclone from November. The annual temperatures are negative, excluding the low north-western periphery. Summer temperatures in conditions of a rugged relief are controlled by cloudiness and the values of the altitude thermal gradient, which increase from 0.5 to 0.7 degrees per $100 \mathrm{~m}$ from northwest to southeast [11]. Generally, within the glaciated part of Altai the temperature at level $2500 \mathrm{~m}$ a.s.l. increases from $5-6^{\circ} \mathrm{C}$ to $9-10{ }^{\circ} \mathrm{C}$ [12]. The general trend of warming and aridization in the direction from northwest to southeast is reflected 
in an increase of equilibrium line altitude (ELA) from 2600-2700 $\mathrm{m}$ a.s.1. in the north-west [11] to $3800 \mathrm{~m}$ and more in the south-east [13].

Although the first scientific data on the existence of glaciers in Altai were obtained by F. Gebler in 1835 [14], until now, almost all estimates of the area and number of modern glaciers in Altai and their recession are limited to its individual parts [15-25]. This is due to the fact that this mountain system is located on the territory of different countries, and since the collapse of the USSR, the problem has only worsened, since the glaciers of the Soviet part of Altai were partly in Kazakhstan, partly in Russia.

Present worldwide trends of glacier recession [26-29] started after the last global glacial advance, caused by cooling known as the Little Ice Age (LIA) [30]. LIA maximum extent was reached at different time points in different areas: this was during the 17th to 19 th century (mostly around 1820 or 1850) in the Alps, in the mid-18th century in Scandinavia and in the early 18th century in New Zealand or parts of Alaska [31].

The systematic glacier observations first started in the 19th century in the Alps [32] (regular glacier front variation surveys began around 1880), in addition, the region has a large number of historical records, historical maps, repeated photographs and paintings. Consequently, the time and extent of the maximal LIA glacial advances are well known in that region $[33,34]$. Large valley glaciers in the Alps have retreated since the Little Ice Age maximum around 1850 [34].

Nevertheless, for most glacial regions, including the Altai mountains, there is no direct observation data on the time of the peak of the LIA glacial advances, which makes it difficult to estimate the scale of the subsequent reduction of glaciers. For such regions it is usually possible to reconstruct the glacierized area of the LIA on a geomorphological basis $[35,36]$ by mapping glacial landforms of former maximal glacier stands and lateral or terminal moraines.

After the LIA, the worldwide glacial retreat was uneven. In the Alps this process is also better known: short oscillations or episodes of glacier standstill took place around 1890, 1920 and 1980 with acceleration in the recent decades [27,34,37-39]. In the Caucasus the readvances took place in the 1910s, 1920s and 1970s-1980s [40]. There is less information about some remote areas with rare population, where most data are based on remote sensing and paleo reconstructions [14,23-27]. For example, in the Altai mountains after the discovery of the glaciers in 1835 , it was only in 1897, that the systematic measurements of the change in the positions of glacial termini began, even though only few glaciers in the Russian part of the mountains were affected. This was largely caused by the remoteness of glaciers from roads and populated areas, as well as the location of some glaciers (for example, the largest glacial center of the Tavan-Bogd massif) on the territory of several states at once, which made it difficult to conduct research. With the availability of free access space images covering the period from the 1960s, it became possible to study in relative detail the last phases of glacier reduction after the LIA maximum.

Thus, the main objectives of this study are:

1. To reconstruct the Altai glaciers to the maximum LIA.

2. To estimate the reduction of the Altai glaciers from the LIA maximum to the present.

3. To analyze the rates of glacier reduction using the example of the second largest glaciation center in Altai - the Tavan Bogd mountain range at seven time points: LIA maximum, 1968, 1977, 1989,2000, 2010, 2021.

Taking into account the scale of the task of reconstructing the glaciers of the LIA maximum for such a large territory, the primary task was to cover the areas previously unexplored in this respect. Therefore, we received results for the territory of the Mongolian, Chinese, east and south of the Russian Altai. For the northwestern regions of Altai, we used the results of reconstructions by other authors [41,42]. Nevertheless, within the framework of our study, for the first time, an estimate is given of the area, number, and spatial distribution of glaciers in the entire Altai in the LIA maximum and their subsequent reduction. 
Our research is based on 3 groups of methods.

\section{Field observations}

Observations of the dynamics of glaciers relate mainly to the period of their reduction after the LIA maximum. The time of the LIA maximum in Altai was not recorded by direct observations. The first observations of the position of the edge of the glacier were made by F. Gebler in 1835 on the Katunsky glacier [14]. In 1835 the glacier may still be advancing, which was indicated on the basis of geomorphological data by P.A. Okishev [41]. According to his opinion, this advance ended in the second half of the 1830s. In 1880 when N.M. Yadrintsev visited the glacier, it had already retreated from its position in 1835 by 350-380 m, and by 1895 the edge of the glacier was $384 \mathrm{~m}$ away from it [41]. Thus, at least for the Katunsky glacier, it is known that its last advance during the LIA ended in the interval 1835-1880, and most likely several years after 1835. From 1897 to 1937, the glacier retreated with an average speed of $15 \mathrm{~m}$ per year, with the highest rates of reduction occurring in 1935-1937 (20.7 m per year). In subsequent years, the periods of rapid shortening of the glacier's length, with rates reaching $45 \mathrm{~m}$ per year, were separated by episodes of a slower retreat of the glacier in 1937-1952, 1961-1965, 1970-1972, 1986-1989, and 1993 [43]. In the North Chuya Range, halting of the retreat of glaciers took place in 1936, 1940, 1969, and 1993 (Right Aktru) and in 1911, 1936, 1960, 1966, 1979, and 1993 (Malyi Aktru) [44]. There are several more large glaciers in Altai the dynamics of which is more or less known for at least the first half of the 20th century.

The first observations of the glaciers of Altai by the geographers of Saint Petersburg State University (our research group) started in 1965 (Mongun-Taiga mountain massif) [45]. Since late 1980-s the continuous monitoring of the glaciers of Altai mountains has been established in a regime of part-time observation stations (hydrological, glaciological, meteorological, geomorphological, and dendrochronological in situ observations were made in the ablation periods). The main polygons of observations are the glaciers of the Mongun-Taiga massif and of the northern slope of Tavan-Bogd massif. In the last 10 years we started observations in other glaciated areas: Ikh Turgen, Tsambagarav, TsengelKhairkhan, Shapshalsky ridge, South Altai ridge [46].

Glaciological observations included monitoring of the positions of the glacial edges, locating the ELA, mass balance observations and mass balance index calculations. Monitoring of the positions of the glacial edges is based on survey activities, such as geodetic surveying, GPS tracking of the glacial edges, measurements of the changes of the glacial length (repeated measurements of the distance between the benchmarks and the glacial edges), the usage of repeated photographs, and remote sensing. The results of this monitoring provide the opportunity to estimate the rates of advance and retreat of the glaciers. The monitoring of the positions of the glacial edges was done for different types of glaciers, but preference was given to the larger valley glaciers that are the most representative glaciers (due to less dependence on geomorphic factors) with the longest observation periods (being at the same time easier to reach due to the lower positions of the snouts).

\section{Remote sensing}

Remote sensing study gives the opportunity to get the information on the present state of the glaciers, to reconstruct the positions of the glaciers in the maximum of the LIA and to fill the gaps between the time points of the field observations. Accordingly, there were 2 groups of satellite imagery: images used for the delineation of the glaciers of the Tavan Bogd massif for the different time points in the past (table 1) and images, used for recent glacier identification for different glaciated areas (table 2). The choice of time points for the imagery was, in many respects, due to the availability of the required satellite images. Also, the images had several requirements: they should correspond to the end of the ablation season, when the height of the snow line is maximal, and the snow cover does not interfere with delineation of the boundaries of glaciers; it is desirable that images have low cloud cover; and, images should not be taken after snowfalls. If in an individual image clouds covered parts of the glacierized area, another image from the nearest available date was collected. 
The imagery of the 1st group (Table 1) is represented mostly by the Landsat images provided by the USGS [47] as well as CORONA image. Spot 5 image was provided by RDC ScanEx [48] and processed by the Space and Geoinformation Technologies Resource Center of Saint Petersburg State University. For Landsat, one common false-color composite (FCC) image combination is provided by TM bands 5, 4, 3, which help delineate clean glacier ice/snow and vegetation (Paul et al. 2004, Bolch and Kamp 2006). For Landsat 7 images we used false-color composites (FCCs) that show the differences in reflectance of landscape features. In particular, we used a Landsat ETM+ and TM 5,4,3 RGB composite (red: channel 5; green: channel 4; blue: channel 3), the resulting effect is that snow and ice are clearly differentiated from clouds, debris, rock, or vegetation due to FCC image color differences [49]. Moreover, Landsat 7 images taken by the ETM+ sensor included a panchromatic band 8 , which was used for pan-sharpening to improve image resolution from $30 \times 30 \mathrm{~m}$ to $15 \times 15 \mathrm{~m}$ employing ESRI ArcGIS 10.4. We also used Landsat 2 MSS 765 and 654 RGB composite.

Table 1. Satellite imagery used in the study of Tavan Bogd glaciers in the past.

\begin{tabular}{|l|l|l|l|}
\hline Date & Spacecraft & Spatial resolution, $m$ & Image ID \\
\hline $2010 / 08 / 31$ & SPOT 5 & 2.5 & SP5_214251_100831 \\
\hline $2000 / 08 / 07$ & Landsat 7 & 15 & LE71440262000220SGS00 \\
\hline $2000 / 08 / 16$ & Landsat 7 & 15 & LE71430262000229SGS00 \\
\hline $1989 / 09 / 03$ & Landsat 4 & 30 & LT41430261989246XXX02 \\
\hline $1977 / 09 / 01$ & Landsat_2 & 60 & LM21540261977244AAA02 \\
\hline $1977 / 08 / 14$ & Landsat_2 & 60 & LM21540261977226AAA03 \\
\hline $1977 / 07 / 28$ & Landsat_2 & 60 & LM21550261977209AAA03 \\
\hline $1968 / 08 / 10$ & CORONA & 1.8 & DS1104-1039DA010-013 \\
\hline
\end{tabular}

The second group (Table 2) is represented mostly by Sentinel-2 imagery with $10 \mathrm{~m}$ maximal spatial resolution. We used natural colour band combination (B04 - B03 - B02). This combination allows not only to determine the spatial position of glaciers, seasonal snow, but also to delineate rock glaciers, moraines, to determine the degree of their overgrowth with vegetation. In some cases, the LIA and recent glaciers area determination had been done before the Sentinel 2 imagery became available. This is why we used Spot 4 imagery for Hunguyn-Nuru, Turgen, Kharkhiraa and Sair (10 m resolution). Also for some areas we managed to get imagery of resolution, higher than Sentinel 2: Spot 5 imagery (2.5 m resolution) for Ikh Turgen, Mongun-Taiga Minor, Tsengel Khairkhan; Spot 6 for Shapshalsky ridge (1.5 m resolution); Geoeye-1 imagery for Talduair massif, Saylugem and Tsambagarav ridges (spatial resolution: $0.5 \mathrm{~m}$ panchromatic and 1.8 multispectral) and WorldView-2 for Mogun-Taiga massif (spatial resolution: $0.5 \mathrm{~m}$ panchromatic and 1.8 multispectral).

Delineation of the recent glaciers and of the geomorphological forms marking their positions in the maximum of the LIA has been done manually. The minimum size of glaciers to be mapped was $0.01 \mathrm{~km}^{2}$.

The systematic error was defined as \pm 1 pixel ( $0.5 \mathrm{~m}$ for Geoeye- 1 and WorldView -2 , $1.8 \mathrm{~m}$ for Corona, $2.5 \mathrm{~m}$ for SPOT 5, $10 \mathrm{~m}$ for Sentinel 2, $15 \mathrm{~m}$ for Landsat 7, $30 \mathrm{~m}$ for Landsat 4 and $60 \mathrm{~m}$ for Landsat 2). Thereby, the error of area determination is calculated by simple formula:

$$
A_{\text {er }}=n \cdot m
$$

where $n$ - number of pixels defining the perimeter of the glacier area, $m$ - spatial resolution of the sensor bands applied expressed as an area of the pixel.

The percentage error of area determinations, $A_{r e r}$, is given by:

$$
A_{\text {rer }}=100 \%(\mathrm{~nm}) / A_{g l}
$$

where $A_{g l}$ - the area of the glacier 
The total systematic error was $5.6 \%$.

To assess the subjective "cartographer's error", we took a sample of 100 glaciers, while within the sample the glacier areas were distributed according to the general distribution of glaciers by area. Within the sample, the glaciers were re-mapped. The error was determined by comparison with the glacier areas obtained in the course of cataloging. The average error for the entire sample was $6.0 \%$.

The main mistakes in determining the boundaries of the glacier are associated with several factors:

1. Debris-covered glacier edges which merge in color with the end moraines of the LIA complex or, on the contrary the areas of dead ice under the moraine adjacent to the glaciers, which is typical for the region. Thus, both underestimation and overestimation of the size of the glacier is possible. For such cases we used indicators defined by Loibl et al. [36]: active ice indicators are "smooth" debris surface, linear flow structures, and constrained tributaries; dead ice indicators are rugged debris surface, melting ponds, unconstrained tributaries, and pioneer plants. We added two more diagnostic signs: for the massifs of of dead ice it is typical when the water flows into tunnels and its exits from other tunnels down the slope; the active glacial edge is marked by marginal flows that join at the lowest point of the glacier [50]. All these indicators work well, with the exception of pioneer plants, which, due to the dry climate of the central and eastern parts of Altai, are absent near the glaciers in those areas and appear only on the surface of inactive rock glaciers. We also tried to use the results of in situ observations whenever possible, which helped to solve this problem in some complicated cases (Figure 2). 


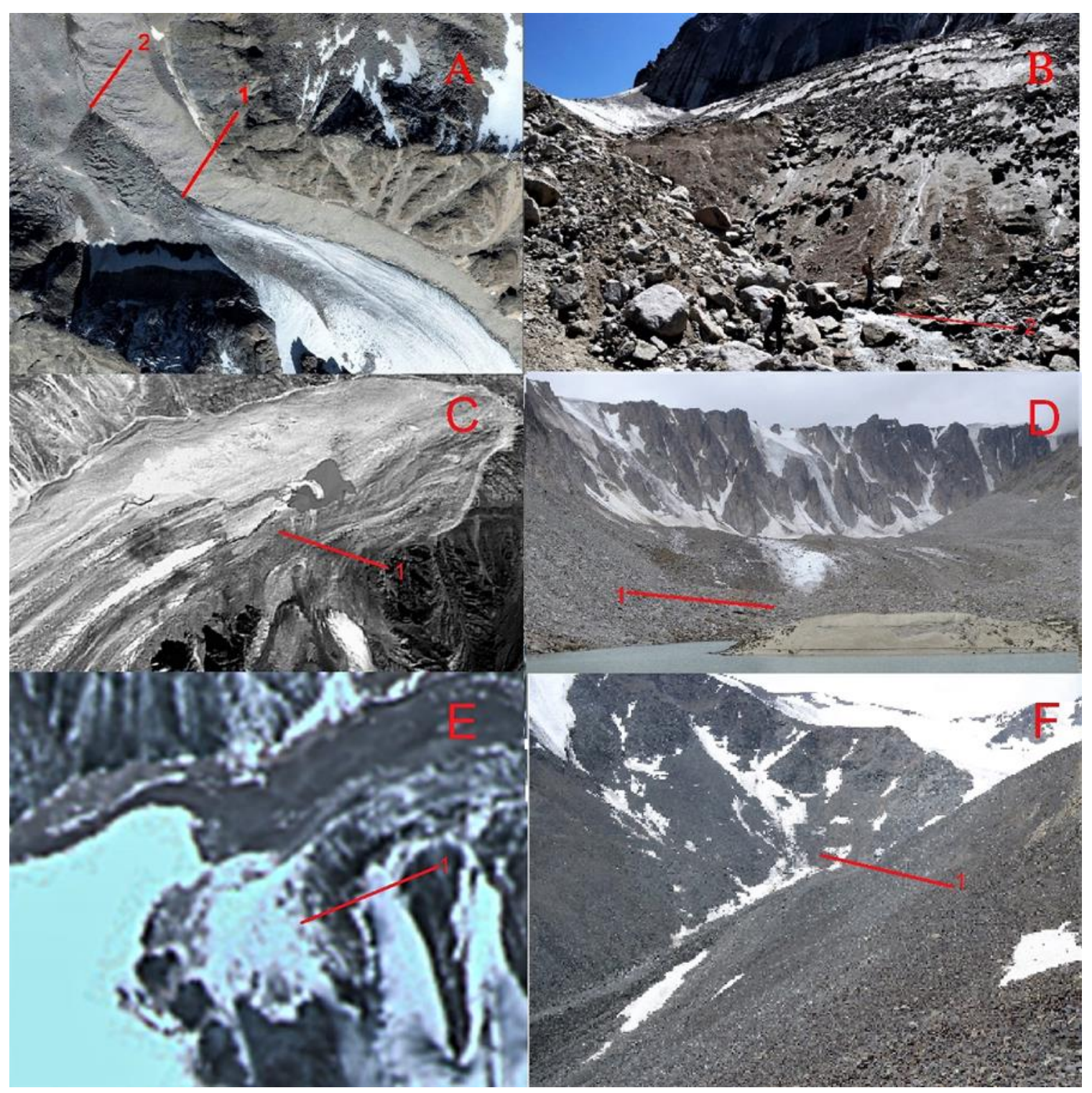

Fig. 2. Areas of satellite images that are problematic for glacier delineation and their photographs obtained in situ. A, B - Grigorieva glacier, Ikh Turgen: 1- false glacier edge based on the interpretation of the satellite image (World View-2, 2013/08/22), 2- the real edge of the glacier, based on the results of in situ observations (photo 24 July, 2015). C,DTsengel-Khairkhan, Holtsutiyn-Gol valley: C, 1- the area that looks like debris-covered glacial snout in the Spot-5 image (2008/08/07), D, 1- the real edge of the glacier, based on the results of field observations (photo 24 July, 2016). E,F- Mongun-Taiga, Levyi Mugur valley: E, 1- the area, that looks like a small cirque glacier in the satellite image (Spot-5 2011/09/19), F,1- the same area in the photo (July 15, 2011) - debris-covered dead ice

2. Other typical problem is overestimation of the glacial area after snowfalls or when the seasonal snow cover has not melted. This problem is solved by the selection of satellite images at the end of the season. In some cases, for example, when the snow cover persists for a long time in the areas of dead ice, to control the interpretation, it is necessary to use images of other months or even years, or, if possible, the results of ground observations (Figure 2 E, F; Figure 3). 


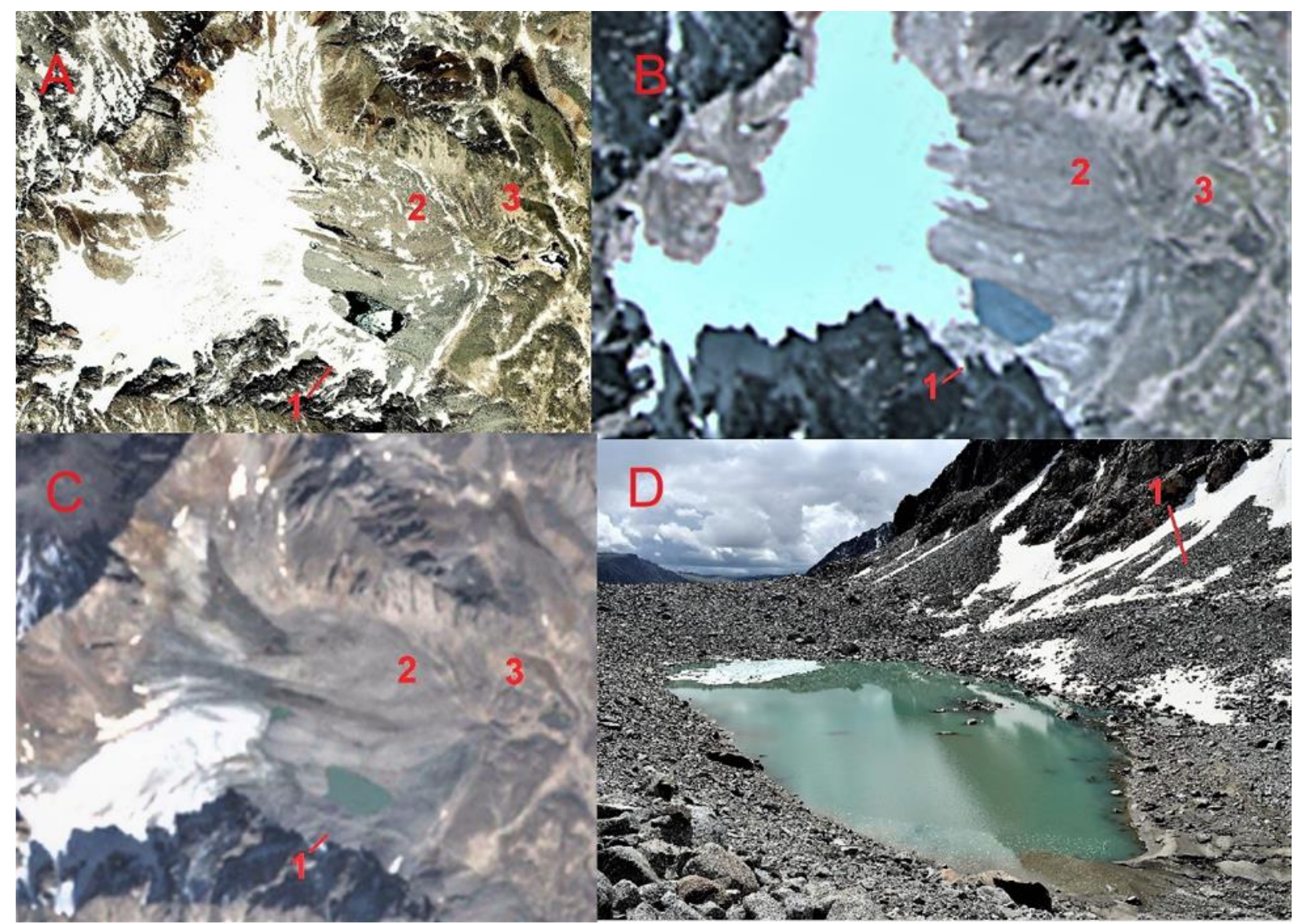

Figure 3. Identification of the LIA moraines and of the present edge of a glacier, Tolayty valley, Mongun-Taiga massif. A- WorldView-2 image, 2015/06/26, B- Spot-5 image, 2011/09/19, C- Sentinel-2 image, 2016/09/06, D- photo, 2019/10/06: 1- snow-covered talus and dead ice (false glacier edge), 2- LIA moraine, 3- Historic stage moraine.

3. Perennial snowpatches and small glaciers are very similar; mistaking snowpatches for glaciers can lead to an overestimation of the glacier area. We were guided by the following distinctive features: glaciers have an integral configuration, while snowfields often have openwork outlines in plan; for glaciers, the images show ablation and accumulation zones; as a rule, crevasses or bergschrunds are visible on the surface of glaciers, which are indicators of glacier movement.

4. The shading of some parts of the glacier and the adjacent non-glacial areas, that usually leads to underestimation of the glacier area. This problem can be solved if the images of the same area with different acquisition times and different angles of sunlight are compared.

5. Medial moraines on the surface of glaciers can often be mistaken for rocky outcrops separating glacial streams. As a rule, in addition to the characteristic position at the contact of the adjacent glacial streams, the medial moraines acquire a convex shape as the surfaces of open ice decrease during the degradation of glaciers. As a result, in some areas the moraine cover crumbles and the ice core of the moraine is exposed, which helps to correctly diagnose it. Such formations should not be excluded from the total area of glaciers, since they move with them, until they lose contact with open areas of the glacier and become independent formations.

6. Frozen glacial lakes can be mistaken for part of a glacial tongue, leading to an overestimation of the glacier area. In this case, if it is not possible to find images for the period when the ice on the lake has already melted, it is possible to use digital elevation models, in which this area will look like an absolutely flat territory, contrasting with the sloped areas of the glacial tongue. 
We used a 30 m SRTM 1 Arc-Second Global DEM [51] to characterize our glacier outlines with parameters including mean, minimum, and maximum elevation ranges, and mean slope and aspect.

Those parameters were determined automatically based on the DEM in the Global Mapper v.18.0 software (digitizer tool). Field data were used to verify the data obtained from remote sensing materials.

Since ELA cannot always be detected on satellite images, especially for small glaciers, for the consistency of the obtained data on ELA, we used the Kurowsky method [52,53] for it identification. In this method the firn line altitude or ELA is calculated as the average altitude of the glacier:

$$
\bar{z}_{f}=\sum_{i} \frac{f_{i} z_{i}}{F}
$$

where $\bar{z}_{f}$ is the firn line altitude or ELA, $f_{i}$ are the areas of the different altitudinal zones of the glacier, $z_{i}$ are the average altitudes of these zones, and $F=\sum_{i} f_{i}$.

Kurovsky method is based on the assumptions that ablation and accumulation on a glacier change linearly with altitude and that the glacier is stationary. The assumption of linearity of changes in ablation with changes in altitude introduces a systematic error associated with the concave nature of the real curve of ablation versus altitude, due to which the ELA lies below the weighted average glacier height. At the same time, errors due to the assumption of linearity of changes in ablation with height and due to the assumption of glacier stationarity have the same sign during the period of glacier advance and opposite during the period of its retreat, i.e. in the second case, they compensate each other, increasing the accuracy of the results. This exactly corresponds to the situation of our study, when glaciers are considered to be in the phase of intense retreat.

Thereby the Kurowsky method has high accuracy in relation to the recent glaciers of Altai. was also used to verify the values of ELA, found by remote sensing. In our work on the current state of the glaciers of the Shapshalsky Center [54], calculations using this method for 30 glaciers gave results close to the ELA position obtained by remote sensing (the average value of the difference was $+2 \mathrm{~m}$ ).

3. Paleo Reconstructions. Reconstruction of the LIA extent of glaciers was done based on geomorphological methods. LIA moraines were mapped using satellite imagery, aerial photos, tachometry, GPS tracking of the lateral and terminal moraines, and visual in situ observations. We used the method of ground-based route interpretation that included descriptions, measurements and photography in reference areas. For object recognition, we used the visual interpretation method according to reference standards [55,56]. The reference standards were compiled from ground-based observations, indicating the following characteristics: characteristic images of objects on the terrain, in the aerial photograph, in the satellite image and in the topographic map; distinctive characteristics of objects; and, methods of transferring objects to the map. The criteria which we used to identify moraines using the satellite imagery and DEM are largely similar to those suggested in [57]: "identification criteria include shadowing due to changes in topography (relative relief) and changes in color due to changes in soil, soil moisture, and vegetation cover. Associated landforms such as deflected abandoned meltwater channels are also useful in delineating the break-of-slope of these features."

Furthermore, we used high-resolution images and compared interpretation results with in situ field observations. For Mongun-Taiga mountain range, we created interpretation standards [58], which we used first for Tavan Bogd massif [50] and subsequently in all other areas studied. A characteristic property of the study area favorable for visual interpretation includes the persistence of glacial topographic features associated with climate aridity, low erosion rates, low rates of biological processes, and poor development of periglacial vegetation cover. Low temperatures, high intensity of frost weathering and 
small precipitation amounts promote a long-lasting preservation of buried glacier ice. All of this causes sharpness of most glacial landforms on aerial photographs and satellite images whose interpretation is made easier by an almost total absence of forest vegetation. Diagnostic features of LIA moraines are their bareness, steep fronts and relatively large thickness, glacial ice cores that are sometimes exposed by thermokarst processes, and position adjacent to modern glaciers. The low turfness of LIA moraines) in multispectral images is expressed by a grey or brown color of moraines in sharp contrast with greenish color of the surrounding subalpine meadows and tundra and the moraines of earlier glacier advances (Figure 3), so they are easily identified. This is particularly characteristic for the LIA moraines which, usually merge or overlap the more ancient moraines of the socalled historical stage [59]. The third characteristic feature is the presence of the ice core of glacial origin. Starting in the late 1990s, an intensification of thermokarst processes on the LIA moraines has given rise to numerous thermokarst depressions, thermoerosional forms and landslides [6], which stand out in steep areas of dumped moraines in the form of sharp and contrasting dark bands visible in images with a resolution better than $15 \mathrm{~m}$.

When delineating LIA moraines, a serious problem is their similarity to rock glaciers, which often leads to an overestimation of the glacier area. In the case of talus stone glaciers [60], the problem of their differentiation from moraines is solved quite simply: they are situated below talus slopes devoid of the glacial exaration forms such as cirques or corries (Figure 4 A,B: 2). On the contrary, debris rock glaciers develop below the LIA moraines or overlap them and move further down the valley (Figure 4, C,D,E: 2). In such cases the reconstructed LIA glacier fronts we placed between the lowest points along the valleys, where the lateral moraines are diagnosed (Figure 4, C,D,E: 1).

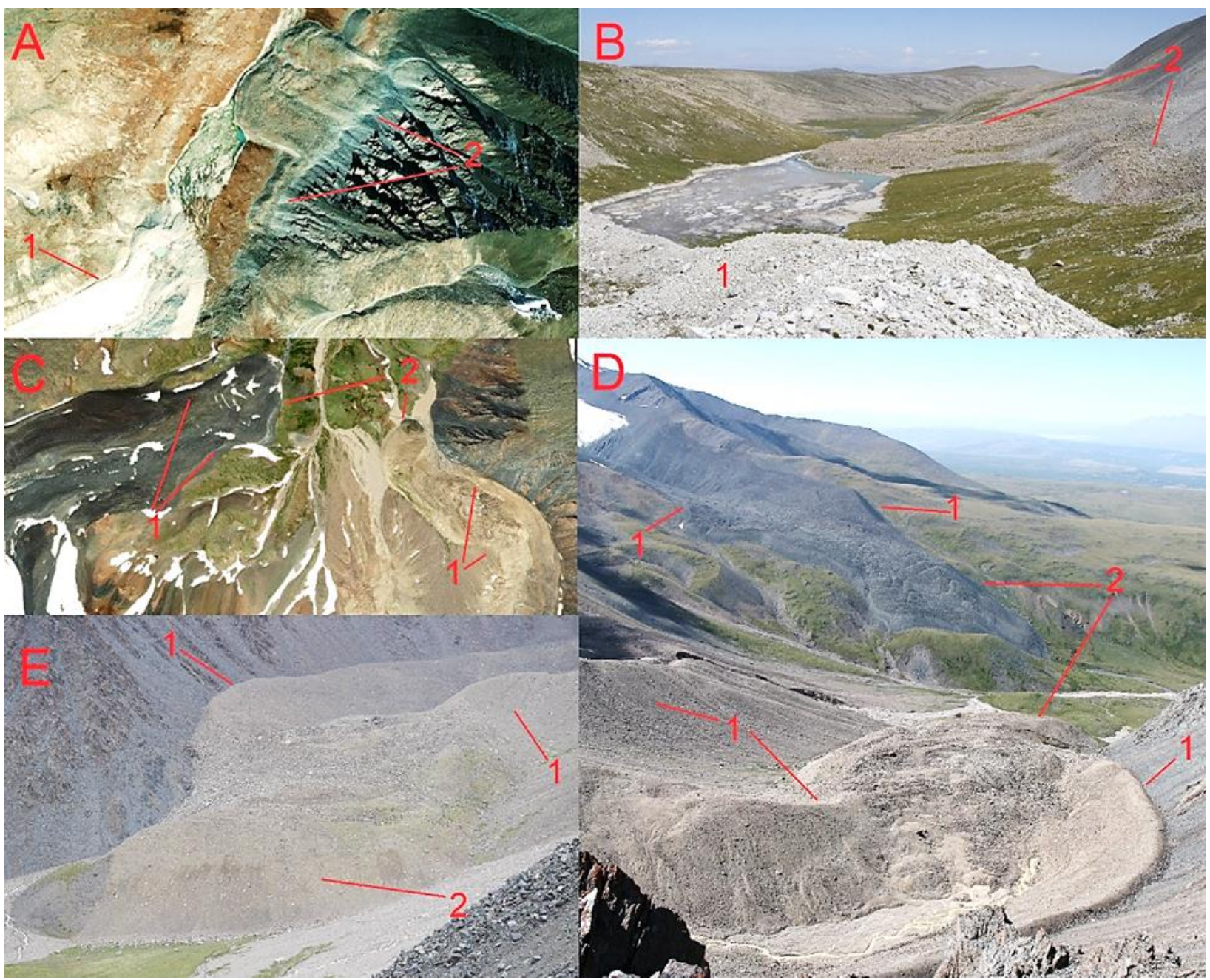

Figure 4. LIA moraines and rock glaciers. Tsengel Khairkhan ridge: A. World View 2 image, 2011/09/18, B. - photo, 31/07/2016: 1- LIA moraine, 2- talus rock glacier. Mongun 
Taiga massif: C - WorldView-2 image, 2015/06/26, D,E - photos 2008/07/28: 1- LIA moraines, 2- debris rock glaciers

Reconstruction of the glaciers of the LIA maximum was carried out not only on the basis of moraine mapping. We used the clear boundaries between unweathered freshly glacially eroded areas and weathered, vegetated areas, in particular fresh glacial erosion marks on the walls of the cirques and troughs in the upper parts of the valleys, corresponding to the LIA moraines located further below the valley.

Much attention was paid to hanging glaciers, traditionally underestimated in paleo reconstructions, which do not form moraines. Diagnostics of such glaciers was carried out on nival niches with sharp outlines, which indicates the recent degradation of the glaciers that formed them. As a rule, such niches are marked with modern snow patches. For some of these glaciers, the degradation process has occurred recently and has been noted by our field observations and satellite and aerial photographs (Figure 5), which makes it possible to use the nival niches that remained in their place as standards of interpretation. 

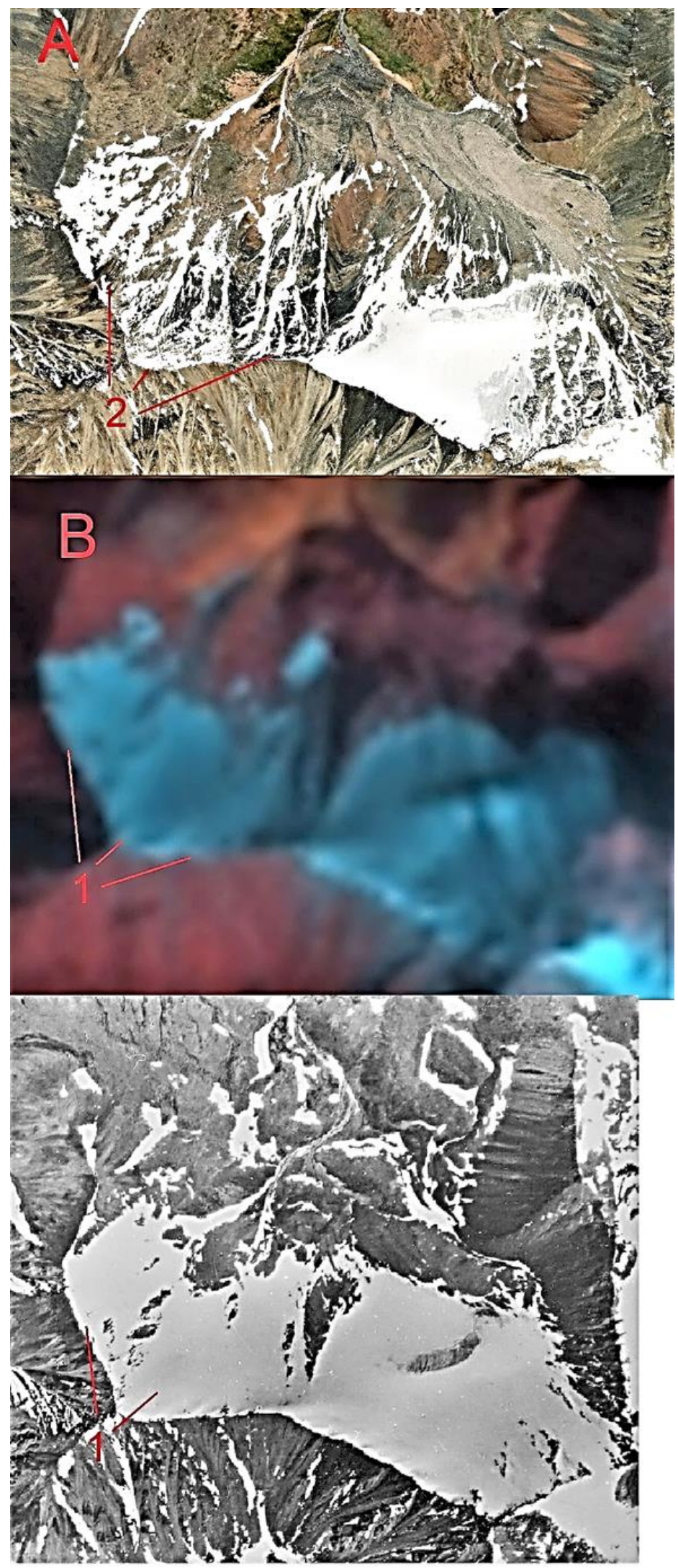

Figure 5. Degradation of hanging glaciers, Mongun Taiga massif. A- WorldView-2 image, 2015/06/26, B- Landsat 5 image, 5,4,3-bands combination, 1987/09/15, C- aerial image, 1966/07/10: 1- degrading small hanging glaciers, 2- nival niches in place of degraded glaciers. 
There is no unambiguity in the estimates of the time of the culmination of the LIA glaciers and the formation of the corresponding moraine in Altai. According to some authors [61], the time of the greatest advance of glaciers corresponded to the 17th century, but most researchers believe that the greatest advance of glaciers belongs to the beginning [62] or to the middle of the 19th century $[25,59,63]$. The time of the LIA maximum in Altai was not recorded by direct observations. P.A. Okishev [41], on the basis of a study of many glaciers of the Russian Altai, came to the conclusion that the last stadial glacial cycle for each of the glaciers developed with some differences from others, i.e. there was no complete similarity in the details of the process. Another important conclusion: the universality of the stage of the 17th - 19th centuries. and a two-fold glacial advance of equal scale. The latter means, on average, approximately the same size of glaciers during periods of movement in the early 17 th and mid-19th centuries.

On the territory of the Mongun-Taiga massif, we carried out temperature and precipitation reconstructions based on dendrochronological data. The reconstructed data made it possible to calculate the mass balance index at the ELA for the valley glaciers of the massif. The transition of the mass balance index to the area of negative values occurred around 1845; Taking into account the inertia of the glaciers, we referred the culmination of the LIA glaciers of the Mongun-Taiga massif to 1845-1855 [25]. With a certain degree of convention, we took 1850 as the average for Altai time of the maximum of the LIA advance of glaciers and the beginning of their reduction.

\section{Results}

To determine the scale of the reduction of glaciers from the LIA maximum, at the first stage of the work, information was obtained on 27 glacial centers in the southern part of Altai (Figure 1, Table 2), together with the information about the other glacial centers of Altai, taken from other sources. This made it possible to obtain a modern estimate of the glaciated area of the entire Altai mountain region- $1096.55 \mathrm{~km}^{2}$.

Table 2. Recent glaciation of Altay mountains.

\begin{tabular}{|l|l|l|l|l|l|l|l|l|l|l|l|l|}
\hline № & Name & $\begin{array}{l}\mathrm{Z}_{\text {max' }} \\
\mathrm{m}\end{array}$ & $\mathrm{N}$ & $\mathrm{S}$ & $\mathrm{S}$ & $\mathrm{A}(\%)$ & $\begin{array}{l}\text { ELA } \\
\mathrm{m}\end{array}$ & Spacecraft, year & $\begin{array}{l}\text { Recent } \\
\text { fobservations, year }\end{array}$ & $\begin{array}{l}\text { The source of } \\
\text { information }\end{array}$ \\
\hline 1 & $\begin{array}{l}\text { Mongun- } \\
\text { Taiga }\end{array}$ & 3970 & 38 & $17.78 \pm 0.06$ & 0.48 & $\mathrm{NE}(40)$ & 3390 & $\begin{array}{l}\text { WorldView-2, } \\
2015\end{array}$ & 2019,2021 & this study \\
\hline 2 & Shapsalsky & 3613,5 & 123 & $14.07 \pm 0.33$ & 0,12 & $\mathrm{NE}(42)$ & 3110 & Spot 6,2015 & 2016 & this study \\
\hline 3 & Ikh Turgen & 4029 & 85 & $29.0 \pm 0.65$ & 0,34 & $\mathrm{~N}(38)$ & 3425 & Spot 5,2011 & 2015 & this study \\
\hline 4 & $\begin{array}{l}\text { Mongun- } \\
\text { Taiga Minor }\end{array}$ & 3718 & 5 & $0.75 \pm 0.006$ & 0.15 & $\mathrm{~N}(46)$ & 3356 & Spot 5,2011 & - & this study \\
\hline 5 & Talduayr & 3506 & 11 & $0.83 \pm 0.009$ & 0.08 & $\mathrm{NE}(46)$ & 3303 & Geoeye 1,2011 & - & this study \\
\hline 6 & Saylugem & 3539 & 7 & $0.19 \pm>0.001$ & 0,03 & $\mathrm{NE}(71)$ & 3218 & Geoeye 1,2014 & 2021 & this study \\
\hline 7 & Tavan Bogd & 4374 & 221 & $192.39 \pm 12.01$ & 0,87 & $\mathrm{~N}(22)$ & 3358 & Sentinel 2,2020 & 2021 & this study \\
\hline 8 & $\begin{array}{l}\text { Tsengel } \\
\text { Khairkhan }\end{array}$ & 3943 & 46 & $10.14 \pm 0.28$ & 0,22 & $\mathrm{NE}(65)$ & 3420 & Spot 5,2008 & 2016 & this study \\
\hline 9 & Sogostyn & 3521 & 10 & $0.25 \pm 0.06$ & 0.03 & $\mathrm{~N}(76)$ & 3375 & Sentinel 2,2020 & - & this study \\
\hline 10 & $\begin{array}{l}\text { Hunguyn- } \\
\text { Nuru }\end{array}$ & 3820 & 31 & $8.51 \pm 0.79$ & 0.27 & $\mathrm{~N}(67)$ & 3390 & Spot 4, 2006 & - & this study \\
\hline 11 & Turgen & 3978 & 69 & $32.45 \pm 2.64$ & 0.47 & $\mathrm{~N}(46)$ & 3475 & Spot 4, 2006 & 1992 & this study \\
\hline 12 & Kharkhiraa & 4037 & 57 & $32.35 \pm 2.63$ & 0.57 & $\mathrm{NE}(61)$ & 3530 & Spot 4, 2006 & 1992 & this study \\
\hline
\end{tabular}




\begin{tabular}{|c|c|c|c|c|c|c|c|c|c|c|}
\hline 13 & Tsambagarav & 4208 & 68 & $68.10 \pm 0.11$ & 1.00 & NE (38) & 3748 & Geoeye-1, 2015 & 2019 & this study \\
\hline 14 & Sair & 3981 & 24 & $6.72 \pm 0.41$ & 0.28 & NE (59) & 3575 & Spot 4, 2006 & - & this study \\
\hline 15 & Huh Serh & 4019 & 25 & $7.00 \pm 0.61$ & 0,28 & $\mathrm{~N}(57)$ & 3642 & Sentinel 2, 2016 & & this study \\
\hline 16 & $\begin{array}{l}\text { Munkh } \\
\text { Khairkhan }\end{array}$ & 4362 & 63 & $26.86 \pm 1.38$ & 0.43 & NE (60) & 3790 & Sentinel 2, 2016 & & this study \\
\hline 17 & $\begin{array}{l}\text { Baatar } \\
\text { Khairkhan }\end{array}$ & 3984 & 4 & $4.74 \pm 0.09$ & 1.18 & $\mathrm{~N}(70)$ & 3807 & Sentinel 2, 2016 & & this study \\
\hline 18 & Sutai & 4220 & 15 & $12.50 \pm 0.12$ & 0.84 & $\mathrm{~N}(55)$ & 3940 & Sentinel 2, 2016 & & this study \\
\hline 19 & $\begin{array}{l}\text { Sargamyr- } \\
\text { Nuru }\end{array}$ & 3842 & 71 & $33.81 \pm 2.86$ & 0,48 & $\mathrm{~N}(49)$ & 3095 & Sentinel-2, 2019 & & this study \\
\hline 20 & Alag-Deliyn & 3624 & 48 & $13.84 \pm 1.21$ & 0.29 & $\mathrm{~N}(59)$ & 3111 & Sentinel-2, 2019 & & this study \\
\hline 21 & $\begin{array}{l}\text { North } \\
\text { Mongolian } \\
\text { Altai } \\
\end{array}$ & 3459 & 30 & $5.97 \pm 0.60$ & 0.20 & $\mathrm{~N}(53)$ & 3014 & Sentinel-2, 2019 & & this study \\
\hline 22 & Hoton & 3507 & 39 & $5.75 \pm 0.75$ & 0.15 & $\mathrm{~N}(74)$ & 3104 & Sentinel-2, 2021 & & this study \\
\hline 23 & $\begin{array}{l}\text { Under- } \\
\text { Khaikhan }\end{array}$ & 3914 & 56 & $17.66 \pm 1.51$ & 0.32 & $\mathrm{~N}(45)$ & 3348 & Sentinel-2, 2019 & & this study \\
\hline 24 & Harit-Nuru & 3868 & 51 & $9.00 \pm 1.00$ & 0.18 & $\mathrm{~N}(75)$ & 3468 & Sentinel-2, 2019 & & this study \\
\hline 25 & $\begin{array}{l}\text { Bayantyn- } \\
\text { Ula }\end{array}$ & 3720 & 30 & $5.48 \pm 0.57$ & 0.18 & $\mathrm{~N}(64)$ & 3385 & Sentinel-2, 2019 & & this study \\
\hline 26 & Eule-Tau & 3660 & 8 & $0.34 \pm 0.07$ & 0.04 & N (94) & 3449 & Sentinel-2, 2019 & & this study \\
\hline 27 & Dushin-Ula & 3876 & 21 & $2.67 \pm 0.37$ & 0.12 & $\mathrm{~N}(56)$ & 3462 & Sentinel-2, 2019 & & this study \\
\hline Tot & al or average & & 1256 & $559.15 \pm 31.13$ & 0.45 & & & & & \\
\hline \multicolumn{11}{|c|}{ The northern part of Altai } \\
\hline 28 & Katunsky & 4506 & - & 198.0 & - & & & Sentinel-2, 2017 & & {$[64]$} \\
\hline 29 & South-Chuya & 3967 & - & 118.0 & - & & & Sentinel-2, 2017 & & {$[64]$} \\
\hline 30 & North-Chuya & 4173 & - & 112.9 & - & & & Sentinel-2, 2017 & & {$[64]$} \\
\hline 31 & \multirow{2}{*}{$\begin{array}{l}\text { South Altai } \\
\text { Kara-Alakha }\end{array}$} & 3871 & 115 & 77.1 & 0.67 & & & $?, 2003$ & & {$[41,65]$} \\
\hline 32 & & 3150 & 27 & 12.2 & 0,45 & & & ?, 2003 & & {$[41,65]$} \\
\hline 33 & \multirow{2}{*}{$\begin{array}{l}\text { Sarymsakty } \\
\text { Kurai }\end{array}$} & 3373 & 49 & 9.3 & 0,19 & & & ?, 2003 & & {$[41,65]$} \\
\hline 34 & & 3446 & 17 & 6.4 & 0,38 & & & ?, 2003 & & {$[41,65]$} \\
\hline 35 & Ivanovskiy & 2775 & 11 & 1.5 & 0,14 & & & ?, 2003 & & {$[41,65]$} \\
\hline 36 & Holzun & 2599 & 6 & 0.8 & 0,13 & & & ?, 2003 & & {$[41,65]$} \\
\hline 37 & Kurkurebazy & 3148 & 4 & 0.4 & 0,10 & & & ?, 2003 & & {$[41,65]$} \\
\hline 38 & Sumulta & 2756 & 3 & 0.4 & 0,13 & & & ?, 2003 & & {$[41,65]$} \\
\hline 39 & Listvyaga & 2577 & 3 & 0.4 & 0,13 & & & ?, 2003 & & {$[41,65]$} \\
\hline \multicolumn{2}{|c|}{ Total or average } & & & 1096.55 & & & & & & \\
\hline
\end{tabular}

It should be noted that the detail of information on the northern part of Altai, which we took from literary sources, is significantly inferior to our data on the southern half of Altai. In addition, the data for a significant part of the glaciation centers in the northern part of Altai date back to 2003, and are therefore very outdated. In addition, in the literature sources that provide data for 2003, it is not indicated on what materials they were obtained. This does not allow us to estimate the measurement error, and the number of glaciers is not indicated either. The information on Katunsky, South-Chuya and North-Chuya 
ridges are up to date, but the information about the systematic errors and the number of the glaciers is absent.

Based on this, our estimate of the modern glacier area throughout Altai should be considered preliminary, probably somewhat overestimated; only the evaluation of the number and area of glaciers in the southern half of Altai can be considered fully reliable: 1256 glaciers with total area $559.15 \pm 31.13 \mathrm{~km}^{2}$.

The most developed are the glaciers in the central part of Altai, where the combination of height and amount of precipitation is optimal for them (Figure 6). To the north, the amount of precipitation increases, but this cannot compensate for the decrease in the height of the mountains. To the east and south, the maximum heights of the mountains do not change significantly, but the amount of precipitation decreases, which is reflected in the reduction in the area of glaciers.

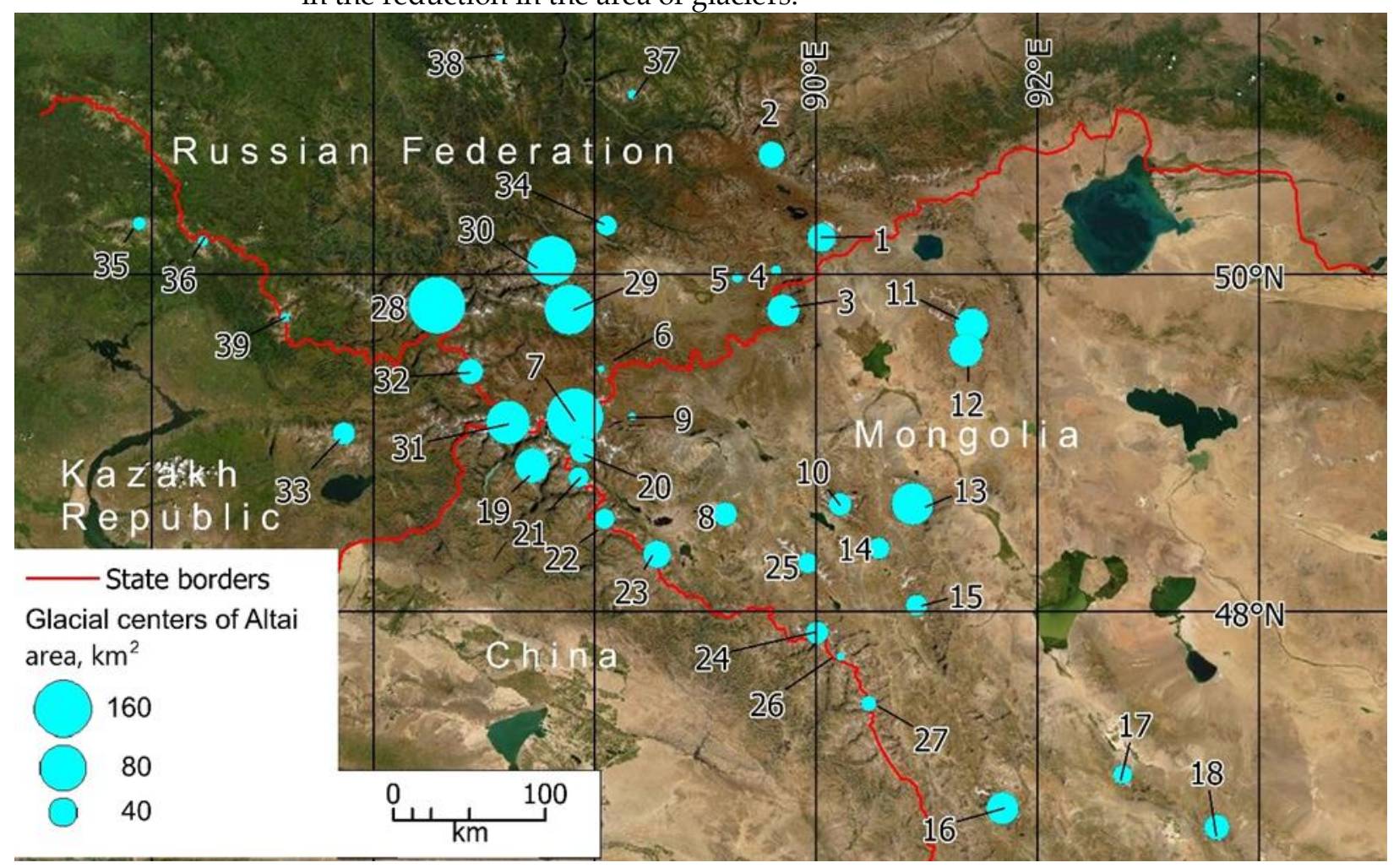

Figure 6. Recent glaciation of Altay mountains. The numbers correspond to the ones in tab. 2

According to our reconstruction, in the southern half of the Altai mountainous country, at the maximum of the LIA, there were 2276 glaciers with total area $1348.43 \mathrm{~km}^{2}$, the subsequent decrease of the total glacier area makes 59\% with average ELA uplift of $106 \mathrm{~m}$ (tab. 3). For the northern part of Altai, we used the only currently available estimate of the glacier area for the LIA maximum, taken from [41,65]. This estimate is very rough and underestimated, since the authors reconstructed mainly large glaciers, excluding completely disappeared glaciers and empty cirques. Taking into account those data we estimate the total area of LIA glaciers of Altai by $2288.04 \mathrm{~km}^{2}$, the subsequent glacier shrinkage by $47.9 \%$. This is the first estimate of the glacier area of the entire Altai mountainous country and their reduction.

Table 3. Glaciers of Altai in the LIA maximum and subsequent glacial recession.

\begin{tabular}{|c|c|c|c|c|c|c|c|c|}
\hline No & Name & $\mathbf{N}$ & $\mathbf{S . ~} \mathbf{K M}^{2}$ & $\mathbf{S a}$ & $\Delta \mathbf{S .} \%$ & $\mathbf{E L A} . \mathbf{m}$ & $\Delta \mathbf{E L A}$ & The source of information \\
\hline 1 & Mongun-Taiga & 86 & $48.04 \pm 0.12$ & 0.56 & 63.0 & 3255 & 135 & this study \\
\hline 2 & Shapsalsky & 358 & $84.43 \pm 1.18$ & 0.24 & 83.4 & 2993 & 117 & this study \\
\hline 3 & Ikh Turgen & 128 & $59.1 \pm 1.01$ & 0.46 & 51.0 & 3360 & 65 & this study \\
\hline
\end{tabular}




\begin{tabular}{|c|c|c|c|c|c|c|c|c|}
\hline 4 & Mongun-Taiga Minor & 8 & $2.91 \pm 0.01$ & 0.26 & 64.3 & 3292 & 64 & this study \\
\hline 5 & Talduayr & 7 & $3.1 \pm 0.01$ & 0.44 & 73.2 & 3186 & 117 & this study \\
\hline 6 & Saylugem & 7 & $1.54 \pm 0.01$ & 0.22 & 87.7 & 3150 & 68 & this study \\
\hline 7 & Tavan Bogd & 247 & $353.4 \pm 15.33$ & 1.43 & 45.6 & 3238 & 120 & this study \\
\hline 8 & Tsengel Khairkhan & 69 & $33.18 \pm 0.54$ & 0.48 & 69.4 & 3350 & 70 & this study \\
\hline 9 & Sogostyn & 22 & $2.02 \pm 0.29$ & 0.09 & 87.6 & 3295 & 80 & this study \\
\hline 10 & Hunguyn-Nuru & 40 & $20.51 \pm 1.24$ & 0.51 & 58.5 & 3314 & 76 & this study \\
\hline 11 & Turgen & 93 & $62.1 \pm 3.60$ & 0.67 & 47.7 & 3440 & 35 & this study \\
\hline 12 & Kharkhiraa & 85 & $78.8 \pm 4.26$ & 0.93 & 58.9 & 3470 & 60 & this study \\
\hline 13 & Tsambagarav & 74 & $128.4 \pm 0.20$ & 1.74 & 47.0 & 3658 & 90 & this study \\
\hline 14 & Sair & 23 & $13.34 \pm 0.63$ & 0.58 & 50.4 & 3510 & 65 & this study \\
\hline 15 & Huh Serh & 79 & $39.58 \pm 1.97$ & 0.50 & 82.3 & 3570 & 72 & this study \\
\hline 16 & Munkh Khairkhan & 99 & $78.67 \pm 2.82$ & 0.79 & 65.9 & 3685 & 105 & this study \\
\hline 17 & Baatar Khairkhan & 2 & $12.94 \pm 0.22$ & 6.47 & 73.4 & 3715 & 92 & this study \\
\hline 18 & Sutai & 54 & $20.58 \pm 0.75$ & 0.38 & 39.3 & 3773 & 167 & this study \\
\hline 19 & Sargamyr-Nuru & 117 & $80.39 \pm 5.21$ & 0.69 & 58.0 & 2942 & 153 & this study \\
\hline 20 & Alag-Deliyn & 62 & $40.09 \pm 2.45$ & 0.65 & 65.0 & 3020 & 91 & this study \\
\hline 21 & North Mongolian Altai & 109 & $31.43 \pm 2.50$ & 0.29 & 81.0 & 2919 & 95 & this study \\
\hline 22 & Hoton & 107 & $29.57 \pm 2.44$ & 0.28 & 81.0 & 2979 & 125 & this study \\
\hline 23 & Under-Khaikhan & 90 & $46.56 \pm 2.76$ & 0.52 & 62.0 & 3207 & 141 & this study \\
\hline 24 & Harit-Nuru & 111 & $34.84 \pm 2.70$ & 0.31 & 74.0 & 3337 & 131 & this study \\
\hline 25 & Bayantyn-Ula & 66 & $19.38 \pm 1.51$ & 0.29 & 72.0 & 3288 & 97 & this study \\
\hline 26 & Eule-Tau & 26 & $2.49 \pm 0.33$ & 0.10 & 86.0 & 3306 & 143 & this study \\
\hline 27 & Dushin-Ula & 107 & $21.65 \pm 2.07$ & 0.20 & 88.0 & 3267 & 195 & this study \\
\hline \multicolumn{2}{|r|}{ Total or average } & 2276 & $1348.43 \pm 56.16$ & & 59.0 & & 106 & \\
\hline 28 & Katunsky & - & 328.7 & - & 39.8 & - & - & {$[41,65]$} \\
\hline 29 & South-Chuya & - & 262.3 & - & 55.0 & - & - & {$[41,65]$} \\
\hline 30 & North-Chuya & - & 208.2 & - & 45.8 & - & - & {$[41,65]$} \\
\hline 31 & South Altai & - & 96.7 & - & 20.3 & - & - & {$[41,65]$} \\
\hline 32 & Kara-Alakha & - & 16.8 & - & 27.4 & - & - & {$[41,65]$} \\
\hline 33 & Sarymsakty & - & 12.9 & - & 27.9 & - & - & {$[41,65]$} \\
\hline 34 & Kurau & - & 9.2 & - & 30.4 & - & - & {$[41,65]$} \\
\hline 35 & Ivanovskiy & - & 2.2 & - & 31.8 & - & - & {$[41,65]$} \\
\hline 36 & Holzun & - & 1.2 & - & 66.6 & - & - & {$[41,65]$} \\
\hline
\end{tabular}




\begin{tabular}{|c|c|c|c|c|c|c|c|c|}
\hline 37 & Kurkurebazy & - & 0.7 & - & 42.9 & - & - & {$[41,65]$} \\
\hline 38 & Sumulta & - & 0.5 & - & 20.0 & - & - & {$[41,65]$} \\
\hline 39 & Listvyaga & - & 0.5 & - & 20.0 & - & - & {$[41,65]$} \\
\hline & Total & & 2288.04 & & 47.9 & & & \\
\hline
\end{tabular}

The analysis of the data obtained did not reveal a clear relationship between the areas of glaciers and their relative reduction (Figure 7). At the same time, there is some regularity: for centers of glaciation with a small area of glaciers, the reduction could be both very high and very small, for large glacial centers, the reduction of glaciers ranged from 44 to $55 \%$. This is explained by the fact that large valley glaciers predominated in large glacial centers, which are least dependent on orographic factors and whose variability will be the most climate-dependent. In glacier centers with a small glacier area, high rates of decline are characteristic of shallow angled slope glaciers, while hanging glaciers located at high altitudes are more resistant to climate change.

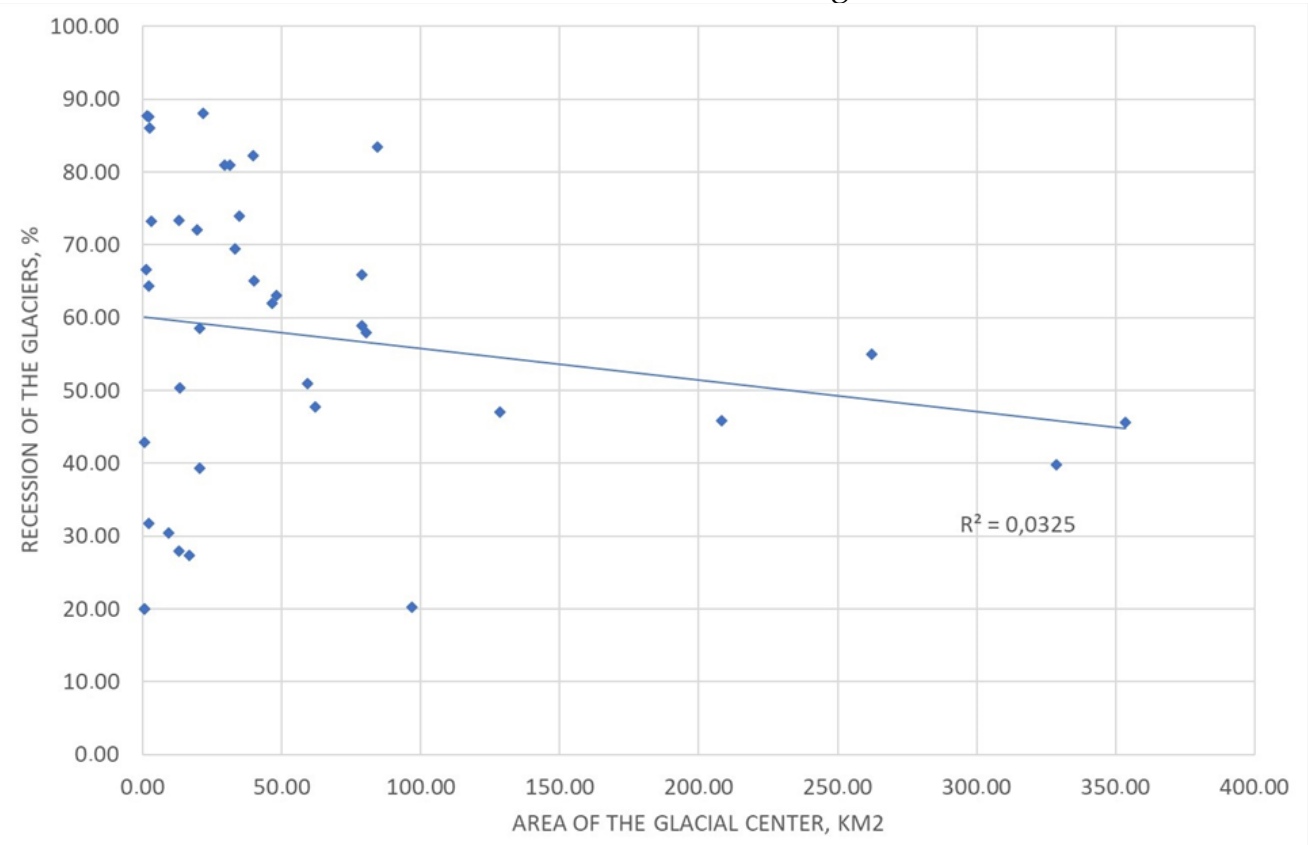

Figure 7. Relationship between the areas of glacial centers at the LIA maximum and the decrease in their area after the LIA maximum, \%.

Analysis of the field of the rise of the ELA in the southern part of Altai (Figure 8) gives grounds to speak of spatial differences in the change in the conditions of existence. On the more humid western and northern periphery of this territory, the rise of the firn boundary was 2 times higher than the rise of the firn boundary in the central and eastern arid part. Since, with a relatively small area of the considered territory, it is difficult to assume significant differences in temperature changes, a more realistic reason for such a difference is a different change in precipitation. Our assumption: after the LIA maximum in the relatively humid part of Altai, the amount of precipitation decreased significantly, while in the more arid part it changed little. 


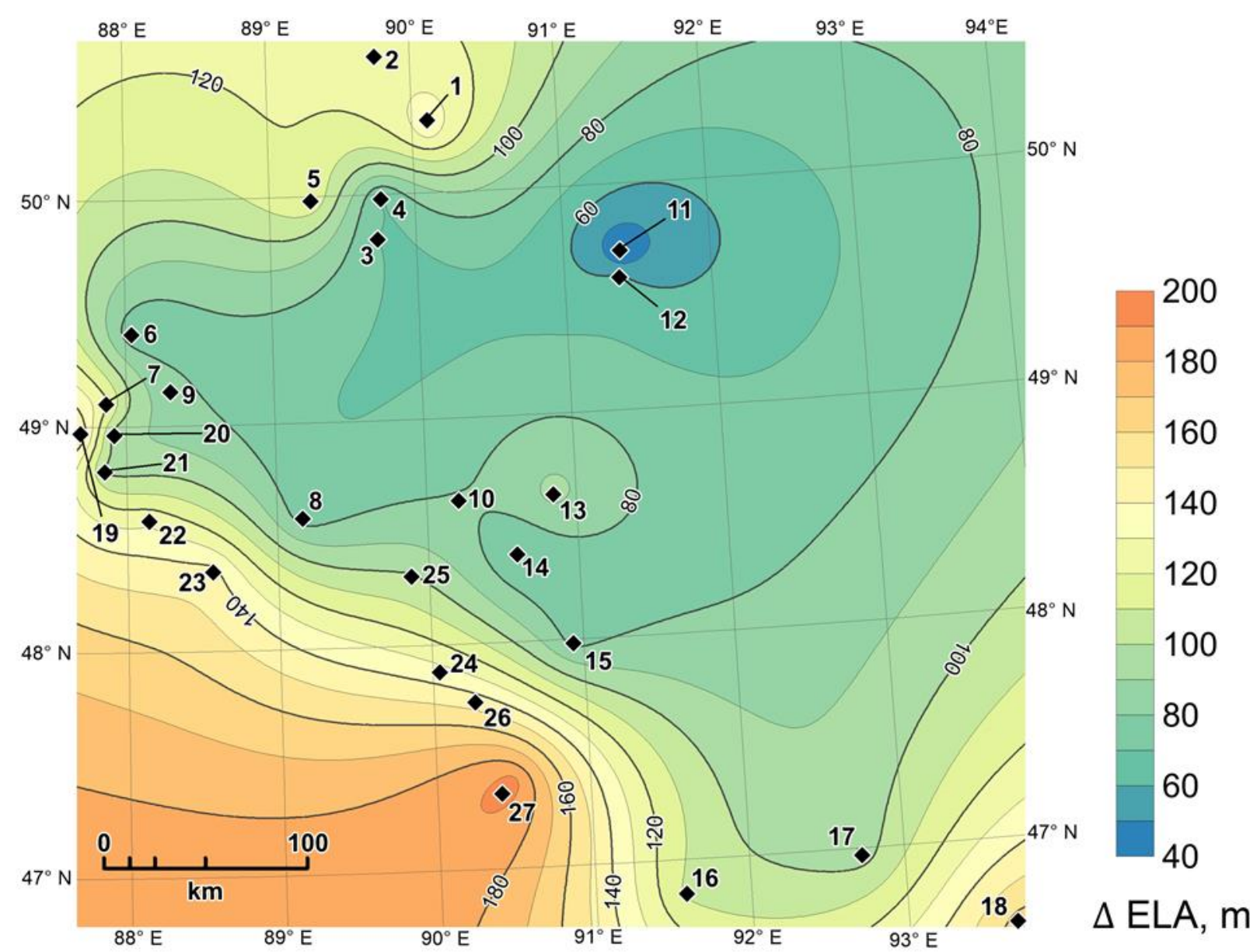

Figure 8. The increase of the ELA after the maximum of the LIA in the southern part of Altai. The numbers of the glacial centers correspond to the ones in Figure 1, Tables 2,3.

The reduction of the Altai glaciers has been and continues to be uneven in speed, but the early stages of this reduction have been little studied. For the largest of the studied centers of glaciation, the Tavan Bogd massif, we studied the reduction of glaciers from the maximum of the LIA, we obtained data on the reduction of glaciers from 1968 to 2020 with an average 10-year interval. The average glacier decrease in the period 1850-1968 was relatively slow (0.66 km/year). Within the interval of $1850-1968$, it is very difficult to determine the internal heterogeneity of the reduction, but there is information about the retreat of some of the largest glaciers (Figure 9). Kanas glacier after 1909 started to retreat more rapidly, increasing the rate from 7.4 to $15.1 \mathrm{~m}$, the retreat once again accelerated in the interval 1916-1959 to $34.2 \mathrm{~m} /$ year. However, in 1959-1968 the retreat decreased abruptly (10 m/year). Following the pattern of the retreat of the Kanas glacier we suggest slow reduction of the glaciers in 1850-1909 with probable periods of glacial stabilization. There are no long-row meteorological stations on the territory of Altai Mountains; most of the meteorological stations have been operating since the 1960s. Using indirect data, such as dendrochronological reconstructions of temperature and precipitation in the Altai region, we can assume similar periods of stabilization after a series of cold summer seasons, such as, for example, around 1883-1884 [66] or 1880 [67]. Another period of glacial stabilization around 1959-1968 is known by direct observations of the Malyi Aktru glacier (NorthChuya ridge) [68] [69] and is marked by series of oscillation moraines within the complexes of the LIA. 


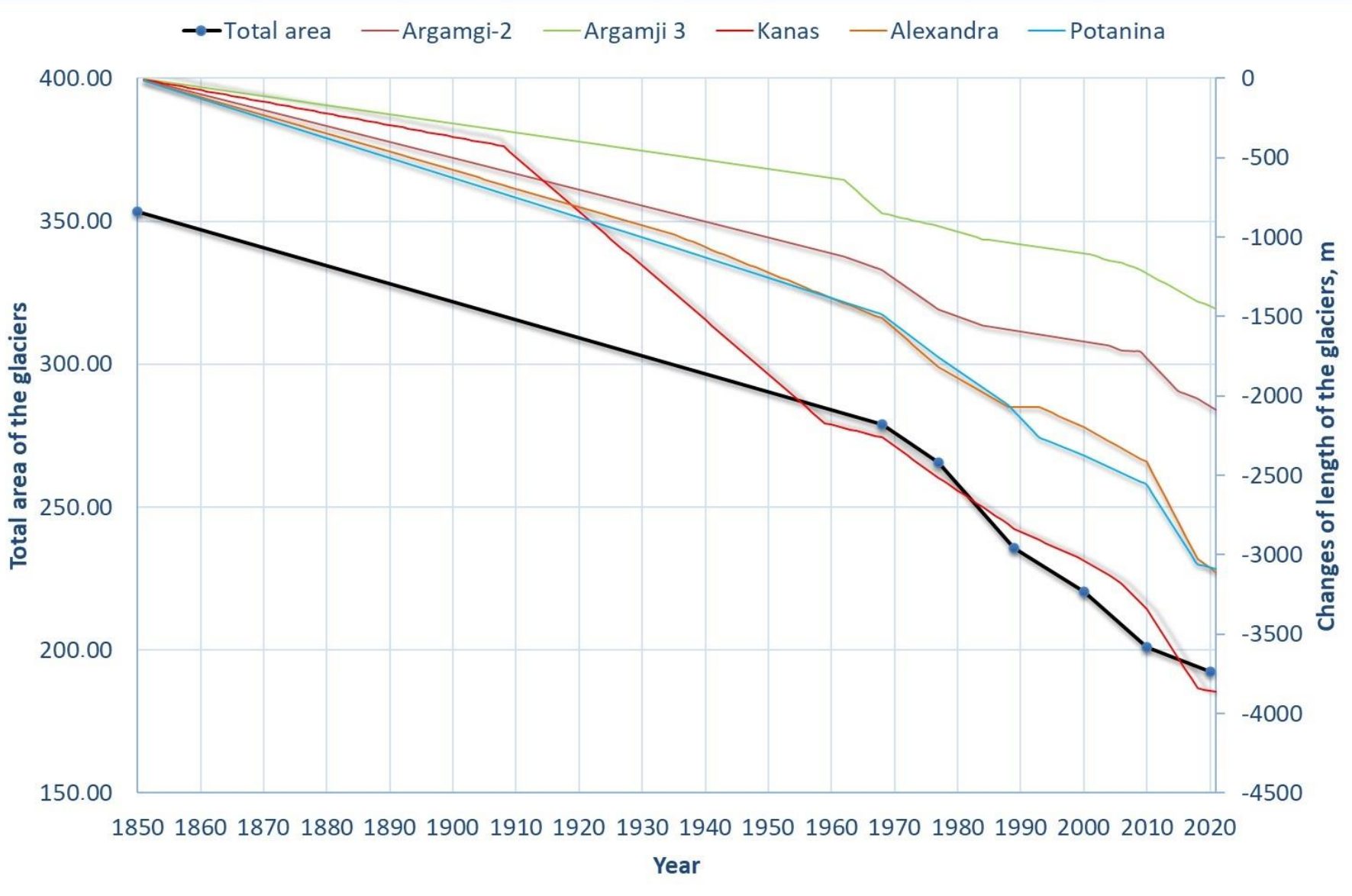

Figure 9. Changes of the total area of the glaciers of Tavan Bogd and the retreat of the termini of 5 valley glaciers after the LIA maximum.

After 1968 the decrease of the glaciers accelerated to average $1.66 \mathrm{~km}^{2} /$ year. The periods of the fastest glacial shrinkage took place in 1977-1989 and 2000-2010. However, the fastest retreat of the valley glaciers took place later - between 2010 and 2018. To understand this behavior of glaciers, let us consider the data on changes in temperature and precipitation from the Kosh-Agach long-row meteorological station closest to the Tavan Bogd massif (Figure 10). The periods with high summer temperature and low precipitation, unfavorable for the glaciers took place in mid-60s, late 70s and in 1989-2004, the second part of the last period mentioned was extremely negative for the glaciers. After 2004, the rise in temperatures slowed down, and the amount of precipitation increased significantly, which made it possible to speak of some stabilization of the climatic conditions of the existence of glaciers at that time. 


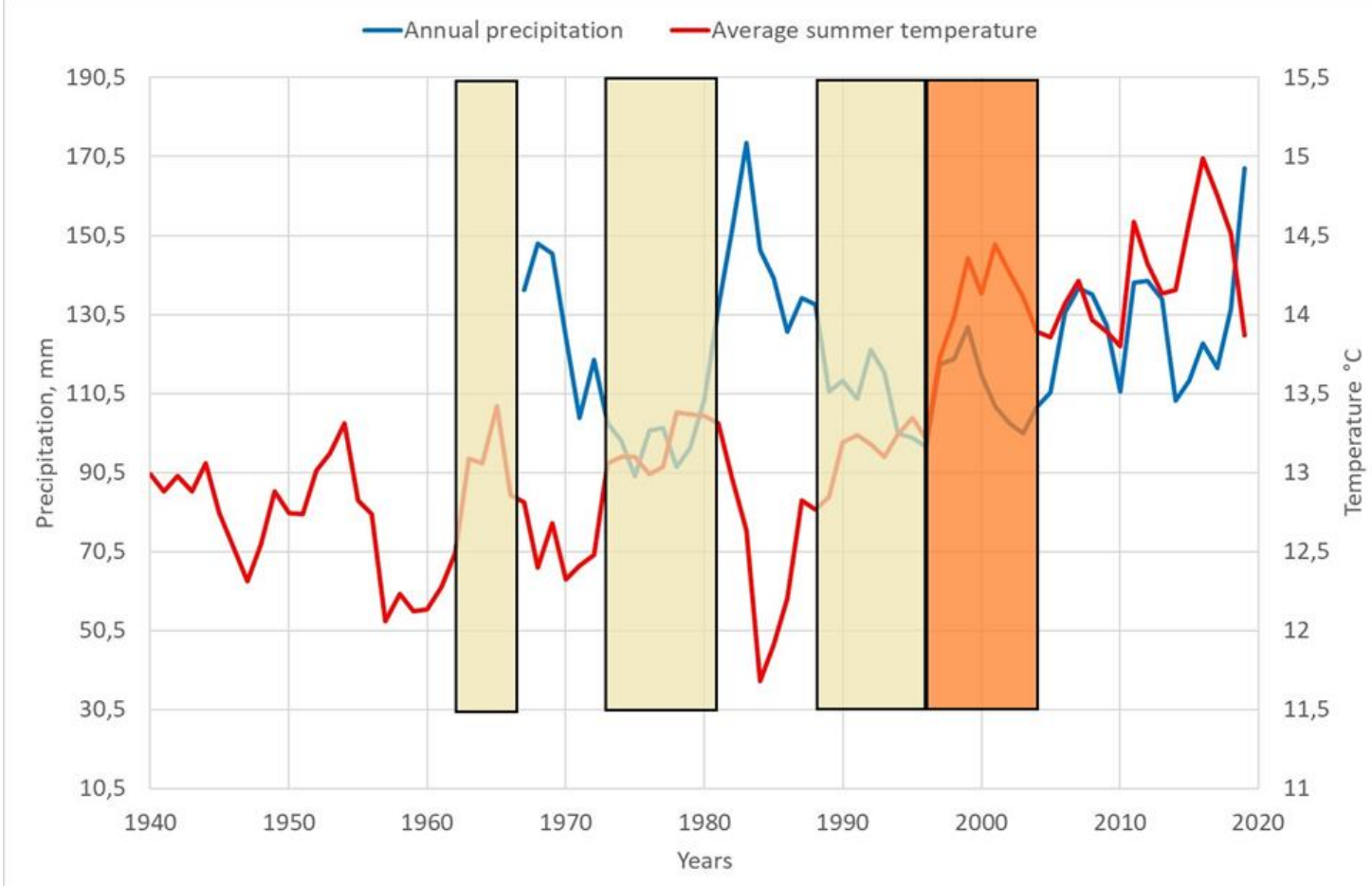

Figure 10. Annual precipitation $(\mathrm{mm})$ and average summer temperature $\left({ }^{\circ} \mathrm{C}\right)$, KoshAgach meteorological station (1758 $\mathrm{m}$ a.s.l.). The periods, unfavorable for the glaciers are marked with yellow bars and orange bar (extremely unfavorable).

Extreme warm and dry period from mid 1990s till mid 2000s is well pronounced at many weather stations in Altay region. That "heatstroke" according to our earlier investigations caused a dramatic decrease in mass balance of the valley glaciers of the northern slope of Tavan Bogd [69]. As a result, many small glaciers disappeared or retreated very fast in the following years (31 small glaciers completely disappeared in Tavan Bogd in this interval), causing a sharp decline of the total glacial area in the period 2000-2010.

However, the reaction of the largest valley glaciers was not immediate due to their higher thickness. For example, we estimated reaction time of the valley glaciers of Argamgi-2 and Argamgi-3 by about 20 years [69]. Thus, the tongues of large glaciers began to shrink rapidly only after 2010. On the contrary, small glaciers in the period 2010-2020 decreased much more slowly, which is associated with the stabilization of climatic conditions.

In the interval 2018-2021, for four of the five examined valley glaciers, a slowdown in retreat was revealed, including the data obtained by in situ observations. Perhaps this is a sign that the glaciers are adjusting to the new climatic conditions and will not be rapidly shrinking in the near future, but it is too early to speak about this with certainty without additional observations.

\section{Discussion}

Estimates of the area and number of modern glaciers in Altai refer to territories bounded by the borders of states, respectively, they were obtained as of different time periods, using various materials and methods. The first catalogue of the glaciers of Altai was made by B. V. Tronov in 1925 [15], it included 408 glaciers with a total area of 590 $\mathrm{km}^{2}$. The next catalogue, created by M. V. Tronov contained 724 glaciers with an area of $600 \mathrm{~km}^{2}$ [70]. In 1960s-1970s the glaciers of Altai were included into the Catalogue of glaciers of the USSR, due to the usage of aerial imagery it was fuller: about 1030 glaciers with a total area of $805 \mathrm{~km}^{2}$. From that period for a long time no catalogization of Russian Altai has been done and the information from the catalogue became outdated. Recently a group of scientist made a new catalogue of the recent glaciers of Russia, based on 2016-2019 Sentinel imagery, according to this research the glaciation of Russian Altai is currently 
represented by 988 glaciers with the total area of $523,1 \pm 38,3 \mathrm{~km}^{2}$. Information on three largest glacial centers of the Russian Altai on basis of this research is given in [64] and was used in our estimate of the total glacier area of all Altai mountainous system. Unfortunately, there are no statistics on other glacial centers of the Russian Altai, which prevents the use of this information for the northern part of Altai in our work.

In Kazakhstan by 2015 there were 116 glaciers with total area $37.212 \mathrm{~km}$ [23]. In Mongolia according to U. Kamp and C. Pan in 2010672 glaciers covered an area of $372.3 \mathrm{~km}^{2}$ [71] (Landsat imagery had been used). In the Chinese Altai 403 glaciers are known with the total area of $280 \mathrm{~km}^{2}$ [18]. We did not aim to evaluate the glaciation of the parts of Altai, belonging to different states, on the contrary we assessed the glaciation of the ridges as a whole, ignoring the administrative boundaries. Therefore, it is hard to compare those estimates with our results.

The most modern assessment of the modern glaciation of the entire Altai currently exists within the framework of Randolf Glacier Inventory: 2446 glaciers $1163 \pm 102 \mathrm{~km}^{2}$, glacier outlines were obtained from Landsat images with acquisition dates between 1999 and 2013 [72]. This is higher than our estimate $\left(1096.55 \mathrm{~km}^{2}\right)$, which is probably due to later dates of the imagery that we have used in the current research (from 2006 to 2020) and that was used for the largest glacial centers of the Russian Altai (2017 [64]), and further degradation of the glaciers between those periods.

Most of the reconstructions of the LIA glaciers of Altai have been done for the Russian Altai $[41,73]$ and they were used in our work for the estimation of the total area of the glaciers of the whole mountainous system. Also, there was a reconstruction of LIA glaciers for Turgen-Kharkhiraa mountains [35], based on field work, topographic maps and aerial photographs, the reconstructed LIA glaciers were compared to their state in 1991. For Turgen Lehmkuhl reconstructed 56 \% reduction of total glacial area from the LIA to 1991 (from 76.7 to $33.8 \mathrm{~km}^{2}$ ) with $\triangle E L A 81 \mathrm{~m}$. This is different from our estimation: $48 \%$ reduction from the LIA to 2006, $\triangle$ ELA $35 \mathrm{~m}$. For Kharkhiraa Lehmkuhl estimated $31 \%$ reduction, $76 \mathrm{~m} \triangle \mathrm{ELA}$; we reconstructed $58 \%$ reduction, $\triangle \mathrm{ELA} 60 \mathrm{~m}$ according to our reconstruction. The difference is mainly caused by the difference in the LIA area reconstructions: though near the snouts of the valley glaciers both reconstructions are very similar, in the upper parts of the glaciers Lehmkuhl gives continuous glacial cover, especially in the eastern parts of both massifs. In our reconstructions there are more bare ice-divides between the glacial flows that reduce the total area of glaciation in the LIA.

In our past publications, we reconstructed in detail the LIA glaciers of different glacial centers of Altai and their gradual reduction [50,74-77]. The first generalization of our data on LIA reconstructions and subsequent reduction of glaciers was made by us for the arid regions of Altai (533 contemporary glaciers with the total area $313.4 \mathrm{~km}^{2}, 450$ LIA glaciers with the total area $635.6 \mathrm{~km}^{2}$ ). Since then, we obtained the data on over 1800 LIA glaciers, including the areas of the south and western slope of Tavan Bogd, the rest of the Mongolian Altai, the whole Chinese Altai and Shapshalsky glacial center in the Russian Altai and updated the information about the recent glaciation of some areas (for example, Tsambagarav). As a result, we obtained a higher percentage of glacier shrinkage from the LIA maximum (59\% instead of 51\% in the earlier publication). Since we included in this study areas with a relatively more humid climate, this may serve as evidence of a more intensive reduction of glaciers in the humid part of Altai and indirect confirmation of our assumption about a decrease in precipitation there after the LIB maximum. However, it will be possible to talk about this with greater awareness after the complete reconstruction of the glaciation of the northern part of Altai in the LIA.

The uneven nature of the reduction of glaciers after the LIB maximum is confirmed by studies on the glaciers of the Russian Altai. The periods of slowdown or stabilization of the glaciers (Katunsky, North-chuya and Katunsky ridges) are marked by oscillation moraines, their age was determined mainly from instrumental measurements and date back to 1909-1914, by the end of the 1920s, by the beginning of the 1930s, by the beginning, by the middle and the end of the 1940s, with general tendencies of slowdown of glacial retreat in the interval 1952-1995 [73]. The newest investigations of the same area show the 
double increase of the area shrinkage rates between 2008-2017 compared to the one in the period 1968-2008 [64]. This partly matches with our data on the increased rates of the glacial shrinkage of Tavan-Bogd glaciers in 2000-2010, of course the behavior of the glaciers of those different glacier centers could be not quite synchronous due to different climatic conditions, morphology, size of the glaciers.

Currently, in different mountainous regions of the world, studies are being carried out on the reconstruction of the glaciers of the LIA maximum and its subsequent reduction. Most of them are local, due to which the results are greatly influenced by the morphological features of glaciers and orographic factors. However, there are regional studies that reveal similarities and differences in the behavior of glaciers in different parts of the world.

For example, in the Alps according to Zemp et al. [34] the total area of the glaciers decreased from $4400 \mathrm{~km}^{2}$ in 1850 to $2900 \mathrm{~km}^{2}$ in 1970 and $2200 \mathrm{~km}^{2}$ by 2020 . This means $54,5 \%$ shrinkage of the glaciers by 2000 already, which is more that we estimated for the Altai region by 2003-2020 (47.9\%). Moreover, there is no doubt that since 2000 the percentage of glacial decrease in the Alps has grown. On the other hand, the data that we have obtained for the southern part of Altai on Altai is more reliable than the estimates for the whole Altai region (due to more up-to date information, higher resolution of reconstruction and unity of the methodological approach, providing more homogeneous results). For the southern part of Altai we estimated a 59\% glacial decrease by 2006-2020, which is closer to the results for the Alps. In order to reasonably compare our data with the data for the Alpine region, let us take the reconstruction of the glaciation of the Tavan Bogd massif, for which we can choose a similar period of 1850-2000. Our results for Tavan Bogd $(37,6 \%)$ show, that glacial shrinkage in Altai has been slower at least until 2000.

F. Paul and T. Bolch [78] analyzed the information of different authors on the changes of the glaciers of the Alps after the Lia and revealed an area loss of about 30 to $40 \%$ (or $0.3 \% / \mathrm{a}$ ) from 1850 to the $1970 \mathrm{~s}$, a further $15-20 \%$ (or 0.6\%/a) from 1973 until 2000 (that mostly occurred after 1985), a further 10-15\% from 2000 to 2010 (or 1.2\%/a), and a total of $50-60 \%$ for the entire period. They also estimated the increase of the ELA roughly by $120-$ $150 \mathrm{~m}$ for the period of 1850-1970. For Tavan Bogd we found 21,1\% area loss for 1850-1968, 16.5\% between 1968 and 2000 and 19,3\% between 2000 and 2010. The ELA increase reached $120 \mathrm{~m}$ only by 2020 . Therefore, Tavan Bogd glaciers generally retreated slower, with the exception of the period of 2000-2010.

Other known reconstructions of the glacial reduction after the LIA are less comparable to our results either because of the different time intervals of glacial shrinkage, local scale of investigations or lack of area shrinkage estimations.

In northern Norway, there was a steady reduction in area ( $\sim 0.3 \%$ per year) between the LIA peak ( 1915) and 1988, which paused between 1988 and 2001, then the rate of recession accelerated to $\sim 1 \%$ per year between 2001 and 2014 [79].

The glacier retreat in the tropical Andes over the last three decades is unprecedented since the peak extent of the LIA (mid-17th-early 18th century). In terms of changes in mass balance, the trend has been quite negative over the past 50 years, with a mean mass balance deficit for glaciers in the tropical Andes that is slightly more negative than the one computed on a global scale. A break point in the trend appeared in the late 1970s, with mean annual mass balance per year decreasing from $-0.2 \mathrm{~m}$ water equivalent. in the period 1964-1975 to $-0.76 \mathrm{~m}$ water equivalent in the period 1976-2010. The retreat was much more pronounced on small glaciers at low altitudes [80].

In the Northern Caucasus since the LIA maximum in the middle of 19th century CE, glacier lengths have decreased by more than $1000 \mathrm{~m}$, and front elevations have risen by more than $200 \mathrm{~m}$ [40].

In the central and western Himalaya, the total length and total area of two hundred and twenty glaciers had decreased respectively by $35 \%$ and $31 \%$ since the LIA, the mean depression of ELAs from the LIA to the first decade of the 21st Century, as reconstructed using the TRAM method, was $123 \mathrm{~m}$ [81]. 
In SE Tibet an average retreat of $\sim 27 \%$ (length change) has been revealed and a trend toward stronger retreat for smaller glaciers, with an average ELA rise of $136 \mathrm{~m}$ since the LIA [36].

Evaluation of the recession of Akshiirak and Ala Archa glacial centers, Tien Shan, central Asia, showed that the area shrinkage of Akshiirak and Ala Archa was $4.2 \%$ and $5.1 \%$, respectively, from 1943 to 1977, and 8.7\% and 10.6\%, respectively, from 1977 to 2003 [82]. In the eastern Terskey-Alatoo Range of the Tien Shan Mountains, mapping of 109 glaciers using the 1965 1:25,000 maps revealed that glacier surface area decreased by $12.6 \%$ of the 1965 value between 1965 and 2003 [83].

In general, all the data on the reduction of glaciers from the LIA maximum are in good agreement with our results for Altai, and the close values of the reconstructed rise of ELA are a possible argument in favor of a similar scale of temperature changes in different mountainous regions of the planet.

\section{Conclusions}

Based on remote sensing data, in situ observations, we made an estimate of the recent glaciation of the southern part of the Altai (1256 glaciers with the total area of $\left.559.15 \pm 31.13 \mathrm{~km}^{2}\right)$. Using the data for the northern part of Altai from other authors we evaluated the area of the glaciers of the whole Altai mountainous $\left(1096.55 \mathrm{~km}^{2}\right)$. The largest present day glacial centers: Tavan Bogd massif $\left(192.39 \mathrm{~km}^{2}\right)$ and Katunsky ridge are situated in the central part of Altai, where the combination of the altitude of the mountains and the amount of precipitation is optimal for the glaciers, to the periphery the glacial area and the size of the glaciers gradually decrease.

We reconstructed the LIA glaciers of the southern part of Altai (2276 glaciers with the total area of $1348.43 \pm 56.16 \mathrm{~km}^{2}$ ) and gave the first estimate of the LIA glacial area for the whole Altai mountain system $\left(2288.04 \mathrm{~km}^{2}\right)$. The glacial shrinkage has been evaluated by $59 \%$ in the southern part of Altai and by $47.9 \%$ for the whole Altai. The ELA in the southern part of Altai increase averagely by $106 \mathrm{~m}$. The spatial distribution of $\triangle$ ELA is probably caused by decrease of precipitation in relatively humid parts of Altai and little changes in its arid parts.

Based on the reconstruction of the Tavan Bogd past and recent glaciation we assume, that the glacial degradation rates increased after mid XX century (1968) relative to the interval between 1850-1968. One of the intervals of the fastest shrinkage of the glaciers in 2000-2010 was caused by unfavorable for the glaciers dry and warm interval 1989-2004, especially the extremal second half of this period (1996-2004). However, the fast decrease of the glaciers in 2000-2010 was mainly caused by the shrinkage or disappearance of the smaller glaciers, large valley glaciers started fast retreat after 2010.

This article is one of the stages of work on the reconstruction of the LIA maximum glaciation for the entire Altai mountainous country. Accordingly, further prospects for this work are the reconstruction of the LIA glaciers for the northern part of Altai, bringing information on modern Altai into uniformity (for example, updating outdated catalogs in accordance with the state of glaciers for 2016-2020), obtaining information on the state of glaciers of the entire Altai for several time sections starting in the mid-20th century to establish spatial and temporal differences in glacier shrinkage. Such work will provide a statistical basis for differences in the behavior of glaciers of different types, climatic conditions of existence, orographic conditions and their different responses to climatic changes. This, in turn, is necessary for a competent forecast of the behavior of glaciers in the future.

Author Contributions: Conceptualization, D.G. and K.C.; methodology, D.G., E.D.,A.T., E.K..; software, A.T.; formal analysis, K.C..; investigation, D.G., E.D., D.B., V.R.; writing - original draft preparation, D.G.; writing - review and editing, D.G.; supervision, D.G., K.C.; project administration, D.G., funding acquisition, D.G.. 
Funding: This research was funded by Russian Foundation for Basic Research (RFBR), grant number №19-05-00535.

Data Availability Statement: the current article.

Acknowledgments: RFBR 19-05-00535 Natural catastrophes and transformation of the landscapes of the southeastern Altai and northwestern Mongolia in the period from the maximum of the last glaciation.

Conflicts of Interest: The authors declare no conflict of interest.". 


\section{References}

1. Haeberli, W. Glacier Fluctuations and Climate Change Detection; 1995; Vol. 18;.

2. Bahr, D.B.; Dyurgerov, M.; Meier, M.F. Sea-Level Rise from Glaciers and Ice Caps: A Lower Bound. Geophysical Research Letters 2009, 36, 4 .

3. Meier, M.F.; Roots, E.F. Glaciers as a Water Resource. Nature and Resources 1982, 18, 7-14.

4. Barnett, T.P.; Adam, J.C.; Lettenmaier, D.P. Potential Impacts of a Warming Climate on Water Availability in Snow-Dominated Regions. Nature 2005, 438, 303-309.

5. Francou, B.; Coudrain, A. Glacier Shrinkage and Water Resources in the Andes. Eos, Transactions, American Geophysical UnionAmerican Geophysical Union 2005, 86, 415.

6. Bradley, R.S.; Vuille, M.; Diaz, H.F.; Vergara, W. Threats to Water Supplies in the Tropical Andes. Science (New York, N.Y.) 2006, 312, 1755-1756.

7. Carey, M. Living and Dying with Glaciers: People's Historical Vulnerability to Avalanches and Outburst Floods in Peru. Global and Planetary Change 2005, 47, 122-134, doi:10.1016/j.gloplacha.2004.10.007.

8. Rudoy, A.N. Glacier-Dammed Lakes and Geological Work of Glacial Superfloods in the Late Pleistocene, Southern Siberia, Altai Mountains. Quaternary International 2002, 87, 119-140, doi:10.1016/S1040-6182(01)00066-0.

9. Chistyakov, K.V.; Ganiushkin, D.A. Glaciation and Thermokarst Phenomena and Natural Disasters in the Mountains of North-West Inner Asia. In Proceedings of the Environmental Security of the European Cross-Border Energy Supply Infrastructure; Culshaw, M.G., Osipov, V.I., Booth, S.J., Victorov, A.S., Eds.; Springer Netherlands: Dordrecht, 2015; pp. 207-218.

10. Vergara, W.; Deeb, A.M.; Valencia, A.M.; Bradley, R.S.; Francou, B.; Zarzar, A.; Grünwaldt, A.; Haeussling, S.M. Economic Impacts of Rapid Glacier Retreat in the Andes. Eos, Transactions, American Geophysical Union 2007, 88, 261-264. 11. Ganyushkin, D.A.; Chistyakov, K.V.; Bueva, M.V. Variability of the Altitude Position of the Firn Line on the Glaciers of the Altai-Sayan Mountainous Country and Its Relation to Climatic Parameters. Proceedings of the Russian Geographical Society 2013, 145, 45-53 (in Russian).

12. Galakhov, V.P.; Red'kin, A.G. Present and Past Glaciation of Tabyn-Bogdo-Ola Mountain Knot. Geography and nature management of Siberia 2001, 4, 153-175 (in Russian).

13. Klinge, M.; Böhner, J.; Lehmkuhl, F. Climate Pattern, Snow- and Timberlines in the Altai Mountains, Central Asia. Erdkunde 2003, 57, 296-308, doi:10.3112/erdkunde.2003.04.04.

14. Tronov, M.V. Essays of the Altai Glacierization.; Geografgiz: Moscow, 1949;

15. Tronov, B.V. Catalog of Altai Glaciers. Bulletin of Russian Geographical Society 1925, 57, 107-159.

16. Katalog Lednikov SSSR. The USSR Glacier Inventory. 1974, 15.

17. Khromova, T.Y.; Nosenko, G.A.; Glazovsky, A.F.; Muraviev, A.Y.; Nikitin, S.A.; Lavrentiev, I.I. New Inventory of the Russian Glaciers Based on Satellite Data (2016-2019). Led i Sneg 2021, 61, 341-358, doi:10.31857/S2076673421030093.

18. Shi, Y.; Huang, M.; Yao, T.; He, Y. Glaciers and Related Environments in China; Sience Press: Beijing, 2008;

19. Shiyin, L.I.U. The 2nd Glacier Inventory of China. 2009, 50, $1-4$.

20. Glacier Inventory of China II. Altai Mountains. [In Chinese with English summary]; Liu, C., You, G., Pu, J., Eds.; Science Press. Academia Sinica, Lanzhou institute of Glaciology and Cryopedology.: Beijing, 1982;

21. Kamp, U.; Krumwiede, B.; Mcmanigal, K.; Pan, C.; Walther, M.; Dashtseren, A. The Glaciers of Mongolia; University of Colorado : Denver, CO, USA: Denver, CO, USA, 2013;

22. Krumwiede, B.S.; Kamp, U.; Leonard, G.J.; Kargel, J.S.; Dashtseren, A.; Walther, M. Recent Glacier Changes in the Mongolian Altai Mountains: Case Studies from Munkh Khairkhan and Tavan Bogd. In Global Land Ice Measurements from Space; Kargel, J.S., Leonard, G.J., Bishop, M.P., Kääb, A., Raup, B.H., Eds.; Springer Berlin Heidelberg: Berlin, Heidelberg, 2014; pp. 481-508 ISBN 978-3-540-79818-7. 
23. Vilesov, N. Changes in the Size and Condition of the Glaciers in Kazakhstan for the Last 60 Years (1955-2015). Led i Sneg 2018, 58, 159-170, doi:10.15356/2076-6734-2018-2-159-170.

24. Kotlyakov, V.M.; Chernova, L.P.; Zverkova, N.M.; Khromova, T.E. The One-and-a-Half-Century Reduction of Altai Glaciers in Russia and Kazakhstan. Doklady Earth Sciences 2014, 458, 1307-1311, doi:10.1134/S1028334X14100286.

25. Ganiushkin, D.; Chistyakov, K.; Kunaeva, E. Fluctuation of Glaciers in the Southeast Russian Altai and Northwest Mongolia Mountains since the Little Ice Age Maximum. Environmental Earth Sciences 2015, 74, 1883-1904, doi:10.1007/s12665-015-4301-2.

26. Oerlemans, J. Extracting a Climate Signal from 169 Glacier Records. Science 2005, 308, 675-677, doi:10.1126/science.1107046.

27. Zemp, M.; Frey, H.; Gärtner-Roer, I.; Nussbaumer, S.U.; Hoelzle, M.; Paul, F.; Haeberli, W.; Denzinger, F.; Ahlstrøm, A.P.; Anderson, B.; et al. Historically Unprecedented Global Glacier Decline in the Early 21st Century. Journal of Glaciology 2015, 61, 745-762, doi:10.3189/2015JoG15J017.

28. Solomina, O.N. Retreat of Mountain Glaciers of Northern Eurasia since the Little Ice Age Maximum. 2000.

29. Solomina, O.N.; Bradley, R.S.; Jomelli, V.; Geirsdottir, A.; Kaufman, D.S.; Koch, J.; McKay, N.P.; Masiokas, M.; Miller, G.; Nesje, A.; et al. Glacier Fluctuations during the Past 2000 Years. Quaternary Science Reviews 2016, 149, 61-90, doi:10.1016/j.quascirev.2016.04.008.

30. Grove, J.M. The Little Ice Age; Methuen: London, 1988;

31. Rabatel, A.; Francou, B.; Jomelli, V.; Naveau, P.; Grancher, D. A Chronology of the Little Ice Age in the Tropical Andes of Bolivia $\left(16^{\circ} \mathrm{S}\right)$ and Its Implications for Climate Reconstruction. Quaternary Research 2008, 70, 198-212, doi:10.1016/j.yqres.2008.02.012.

32. Forel, F.-A. Les Variations Périodiques Des Glaciers. Discours Préliminaire. Archives des Sciences Physiques et Naturelles 1895, 34, 209-229.

33. Holzhauser, H.; Zumbühl, H.J. To the History of the Lower Grindelwald Glacier during the Last 2800 Years Paleosols, Fossil Wood and Pictorical Records - New Results. Zeitschrift für Geomorphologie, N.F. Suppl. Bd. 1996, 104, 95-127.

34. Zemp, M.; Paul, F.; Hoelzle, M.; Haeberli, W. Glacier Fluctuations in the European Alps, 1850-2000: An Overview and Spatio-Temporal Analysis of Available Data. In Darkening Peaks: Glacier Retreat, Science, and Society; 152-167; 2008.

35. Lehmkuhl, F. Holocene Glaciers in the Mongolian Altai: An Example from the Turgen-Kharkhiraa Mountains. Journal of Asian Earth Sciences 2012, 52, 12-20, doi:10.1016/j.jseaes.2011.11.027.

36. Loibl, D.; Lehmkuhl, F.; Grießinger, J. Reconstructing Glacier Retreat since the Little Ice Age in SE Tibet by Glacier Mapping and Equilibrium Line Altitude Calculation. Geomorphology 2014, 214, 22-39, doi:10.1016/j.geomorph.2014.03.018.

37. Patzelt, G. The Period of Glacier Advances in the Alps, 1965 to 1980. Zeitschrift für Gletscherkunde und Glazialgeologie 1985, 21, 403-407.

38. Zasadni, J. The Little Ice Age in the Alps : Its Record in Glacial Deposits and Rock Glacier Formation. Landform evolution in mountain areas 2007, XLI, 117-137.

39. Colucci, R.R.; Žebre, M. Late Holocene Evolution of Glaciers in the Southeastern Alps. Journal of Maps 2016, 12, 289-299, doi:10.1080/17445647.2016.1203216.

40. Solomina, O.; Bushueva, I.; Dolgova, E.; Jomelli, V.; Alexandrin, M.; Mikhalenko, V.; Matskovsky, V. Glacier Variations in the Northern Caucasus Compared to Climatic Reconstructions over the Past Millennium. Global and Planetary Change 2016, 140, 28-58, doi:10.1016/j.gloplacha.2016.02.008.

41. Okishev, P.A. Rel'efi Oledenenie Russkogo Altaja; Izd. Tom. un-ta: Tomsk, 2011;

42. Narozhnyj, Ju.K.; Nikitin, S.A. The Modern Glaciation of Altai at the Turn of the 21st Century. Data of Glaciological studies 2003, 95, 93-11 (in Russian). 
43. Narozhny, Ju.K.; Nikitin, S.A.; Borodavko, P.S. Glaciers of the Belukha Mountain Knot (Altai): Mass Exchange, Dynamics and Ice Resourses Distribution. Data of Glaciological studies 2006, 101, 117-128.

44. Narozhnyj, Ju.K. Resursnaja Ocenka i Tendencii Izmenenija Lednikov v Bassejne Aktru (Altaj) Za Poslednie Poltora Stoletija. Resource Assessment and Trends in Glacier Change in the Aktru Basin (Altai) over the Past Century and a Half. Data of Glaciological studies 2001, 90, 117-125 (in Russian).

45. Seliverstov, Yu.P. Modern Glaciation of Mungun-Taiga (South-West of Tuva). Bulletin of All-Union Geographical Society 1972, 104, 40-44 (in Russian).

46. Ganyushkin, D.A.; Chistyakov, K.V.; Volkov, I.V.; Bantcev, D.V.; Kunaeva, E.P.; Terekhov, A.V. Present Glaciers and Their Dynamics in the Arid Parts of the Altai Mountains. Geosciences (Switzerland) 2017, 7, doi:10.3390/geosciences7040117.

47. USGS. Available online: https://earthexplorer.usgs.gov/ (accessed on 1 May 2017).

48. Scanex. Available online: www.scanex.ru (accessed on 1 May 2017)

49. Kääb, A.; Bolch, T.; Casey, K.; Heid, T.; Kargel, J.S.; Leonard, G.J.; Paul, F.; Raup, B.H. Glacier Mapping and Monitoring Using Multispectral Data. In Global Land Ice Measurements from Space; Kargel, J.S., Leonard, G.J., Bishop, M.P., Kääb, A., Raup, B.H., Eds.; Springer Berlin Heidelberg: Berlin, Heidelberg, 2014; pp. 75-112 ISBN 978-3-540-79818-7.

50. Ganyushkin, D.; Chistyakov, K.; Volkov, I.; Bantcev, D.; Kunaeva, E.; Andreeva, T.; Terekhov, A.; Otgonbayar, D. Present Glaciers of Tavan Bogd Massif in the Altai Mountains, Central Asia, and Their Changes since the Little Ice Age. Geosciences 2018, 8, 414, doi:10.3390/geosciences8110414.

51. Earth Resources Observation and Science (EROS) Center Available online: https://eros.usgs.gov/ (accessed on 3 April 2018).

52. Kurowsky, L. Die Hohe Der Schneegrenze Mit Besonderer Berucksichtigung Der Finsteraargorngruppe. Pencks Geogr. Abhandlungen 1891, 5, 115-160 (in German).

53. Glazyrin, G.E. Distribution and Regime of Mountain Glaciers; Hydrometeoizdat: Leningrad, 1985;

54. Ganyushkin, D.A.; Konkova, O.S.; Chistyakov, K.V.; Ekaykin, A.A.; Volkov, I.V.; Bantcev, D.V.; Terekhov, A.V.; Kunaeva, E.P.; Kurochkin, Yu.N. The State of the Shapshalsky Glacierization Center (Eastern Altai) in 2015. Led i Sneg 2021, 61, 38-57, doi:10.31857/S2076673421010070.

55. Akovetskii, V.I. Image Interpretation; Nedra: Moscow, 1983;

56. Labutina, L.A. Nterpretation of Aerospace Images. Manual.; Aspekt-Press: Moscow, 2004;

57. Blomdin, R.; Heyman, J.; Stroeven, A.P.; Haettestrand, C.; Harbor, J.M.; Gribenski, N.; Jansson, K.N.; Petrakov, D.A.; Ivanov, M.N.; Alexander, O.; et al. Glacial Geomorphology of the Altai and Western Sayan Mountains, Central Asia. Journal of Maps 2016, 12, 123-136, doi:10.1080/17445647.2014.992177.

58. Ganyushkin, D.A.; Kunaeva, E.P.; Chistyakov, K.V.; Volkov, I.V. Interpretation of Glaciogenic Complexes From Satellite Images of the Mongun-Taiga Mountain Range. Geography and Natural Resources 2018, 39, doi:10.1134/S1875372818010092.

59. Agatova, A.R.; Nazarov, A.N.; Nepop, R.K.; Rodnight, H. Holocene Glacier Fluctuations and Climate Changes in the Southeastern Part of the Russian Altai (South Siberia) Based on a Radiocarbon Chronology. Quaternary Science Reviews 2012, 43, 74-93, doi:10.1016/j.quascirev.2012.04.012.

60. Barsch, D. Rockglaciers: Indicators for the Present and Former Geoecology in High Mountain Environments.; 1996. 61. Ivanovskiy, L.N.; Panychev, V.A. Razvitie i Vozrast Konechnyh Moren XVII-XIX vv. Lednikov Ak-Turu Na Altae. In Processy sovremennogo rel'efoobrazovanija v Sibiri.; Nauka: Irkutsk, 1978; pp. 127-138.

62. Nazarov, A.N.; Myglan, V.S.; Orlova, L.A.; Ovchinnikov, I.Y. Activity of Maly Aktru Glacier (Central Altai) and Changes Tree Line Fluctuations in Its Basin for a Historical Period. Ice and Snow 2016, 56, 103-118, doi:10.15356/20766734-2016-1-103-118. 
63. Adamenko, M.F.; Syubaev, A.A. Dinamika Klimata Na Territorii Gornogo Altaja v XV - XX Vekah Po Dannym Dendrohronologii. In Voprosy gornoj gljaciologii; Izd. Tom. un-ta: Tomsk, 1977; pp. 196-202.

64. Toropov, P.A.; Aleshina, M.A.; Nosenko, G.A.; Khromova, T.E.; Nikitin, S.A. Modern Deglaciation of the Altai Mountains: Effects and Possible Causes. Russian Meteorology and Hydrology 2020, 45, 368-376, doi:10.3103/S1068373920050088.

65. Nosenko, G.A.; Nikitin, S.A.; Khromova, T.E. Glacier Area and Volume Changes in the Mountain Altai (Russia) since the Mid-Twentieth Century from Space Imagery Data. Ice and Snow 2015, 126, 5, doi:10.15356/2076-6734-2014-2-513.

66. Myglan, V.S.; Oidupaa, O.Ch.; Vaganov, E.A. A 2367-Year Tree-Ring Chronology for the Altay-Sayan Region (Mongun-Taiga Mountain Massif). Archaeology, Ethnology and Anthropology of Eurasia 2012, 40, 76-83.

67. Ganiushkin, D.; Chistyakov, K.; Kunaeva, E. Fluctuation of Glaciers in the Southeast Russian Altai and Northwest Mongolia Mountains since the Little Ice Age Maximum. Environmental Earth Sciences 2015, 74, doi:10.1007/s12665-0154301-2.

68. Galakhov, V.P.; Samoilova, S.Yu.; Shevchenko, A.A.; Sheremetov, R.T. Fluctuation of Maly Aktru Glacier (Russian Altai) for the Period of Instrumental Observations from 1952 to 2013. Earth's Cryosphere 2015, 19, 81-86.

69. Galakhov, V.P.; Muhametov, R.M. The Glaciers of Altai.; Nauka: Novosibirsk, 1999;

70. Tronov, M.V. Ocherki Oledeneniya Altaya. Essays of the Altai Glacierization.; Geografgiz: Moscow, 1949;

71. Kamp, U.; Pan, C.G. Inventory of Glaciers in Mongolia, Derived from Lanfsat Imagery from 1989 to 2011. Geografiska Annaler: Series A, Physical Geography 2015, 97, 653-669, doi:10.1111/geoa.12105.

72. Earl, L.; Gardner, A. A Satellite-Derived Glacier Inventory for North Asia. Annals of Glaciology 2016, 57, 50-60, doi:10.3189/2016AoG71A008.

73. Narozhny, Yu.K.; Okishev, P.A. Dynamics of Altay glaciers in regression phase of Little Ice Age. Data of Glaciological studies 1999, 87, 119-123.

74. Ganjushkin, D.A.; Moskalenko, I.G.; Seliverstov Yu, P. The Glaciation of Mongun-Taiga Massif OJIE (Inner Asia) in Maximum of Little Glacial Epoch and Its Evolution. Vestnik Sankt-Peterburgskogo Universiteta, Seriya Geologiya $i$ Geografiya 1998, 7.

75. Ganyushkin, D.A.; Chistyakov, K.V.; Kunaeva, E.P.; Volkov, I.V.; Bantsev, D.V. Current Glaciation of the Chikhachev Ridge (South-Eastern Altai) and Its Dynamics after Maximum of the Little Ice Age. Ice and Snow 2016, 56, 29-42 (in Russian), doi:10.15356/2076-6734-2016-1-29-42.

76. Ganyushkin, D.A.; Otgonbayar, D.; Chistyakov, K.V.; Kunaeva, E.P.; Volkov, I.V. Recent Glacierization of the Tsambagarav Ridge (North-Western Mongolia) and Its Changes since the Little Ice Age Maximum. Ice and Snow 2016, 56, 437-452, doi:10.15356/2076-6734-2016-4-437-452.

77. Ganyushkin, D.A.; Konkova, O.S.; Chistyakov, K.V.; Bantcev, D.V.; Terekhov, A.V.; Kunaeva, E.P.; Kurochkin, Y.N.; Andreeva, T.A.; Volkova, D.D. Ice and Snow. Shrinking of the glaciers of East Altai (Shapshal Center) after the maximum of the Little Ice Age 2021, 61, 500-520.

78. Paul, F.; Bolch, T. Glacier Changes Since the Little Ice Age. In Geomorphology of Proglacial Systems: Landform and Sediment Dynamics in Recently Deglaciated Alpine Landscapes; Heckmann, T., Morche, D., Eds.; Springer International Publishing: Cham, 2019; pp. 23-42 ISBN 978-3-319-94184-4.

79. Stokes, C.R.; Andreassen, L.M.; Champion, M.R.; Corner, G.D. Widespread and Accelerating Glacier Retreat on the Lyngen Peninsula, Northern Norway, since Their “Little Ice Age" Maximum. Journal of Glaciology 2018, 64, 100-118, doi:10.1017/jog.2018.3.

80. Rabatel, A.; Francou, B.; Soruco, A.; Gomez, J.; Cáceres, B.; Ceballos, J.L.; Basantes, R.; Vuille, M.; Sicart, J.E.; Huggel, C.; et al. Current State of Glaciers in the Tropical Andes: A Multi-Century Perspective on Glacier Evolution and Climate Change. Cryosphere 2013, 7, 81-102, doi:10.5194/tc-7-81-2013. 
81. Qiao, B.; Yi, C. Reconstruction of Little Ice Age Glacier Area and Equilibrium Line Attitudes in the Central and Western Himalaya. Quaternary International 2017, 444, 65-75, doi:10.1016/j.quaint.2016.11.049.

82. Aizen, V.B.; Kuzmichenok, V.; Surazakov, A.B. Glacier Changes in Central and Northern Tien Shan during the Last 140 Years Based on Surface and Remote Sensing Data. Annals of Glaciology 2006, 43, 202-213.

83. Kutuzov, S.; Shahgedanova, M. Glacier Retreat and Climatic Variability in the Eastern Terskey-Alatoo, Inner Tien Shan between the Middle of the 19th Century and Beginning of the 21st Century. Global and Planetary Change 2009, 69, 59-70, doi:10.1016/j.gloplacha.2009.07.001.

1. on Day Month Year). 